\title{
Determining if Telehealth Can Reduce Health System Costs: Scoping Review
}

Centaine L Snoswell ${ }^{1,2}$, PhD, MPH, BPharm; Monica L Taylor ${ }^{1,2}$, MPH, BSc (Hons); Tracy A Comans ${ }^{2}$, PhD, BEcon, BPT; Anthony C Smith ${ }^{1,2,3}$, PhD, MEd, BNurs; Leonard C Gray ${ }^{2}$, PhD, MMed, MBBS; Liam J Caffery ${ }^{1,2}$, PhD, DipAppSci, BInfoTech

${ }^{1}$ Centre for Online Health, The University of Queensland, Brisbane, Australia

${ }^{2}$ Centre for Health Services Research, The University of Queensland, Brisbane, Australia

${ }^{3}$ Centre for Innovative Medical Technology, University of Southern Denmark, Odense, Denmark

\section{Corresponding Author:}

Liam J Caffery, PhD, DipAppSci, BInfoTech

Centre for Online Health

The University of Queensland

Building 33, Princess Alexandra Hospital

Brisbane,

Australia

Phone: 61731767704

Email: 1.caffery@uq.edu.au

\section{Abstract}

Background: Telehealth represents an opportunity for Australia to harness the power of technology to redesign the way health care is delivered. The potential benefits of telehealth include increased accessibility to care, productivity gains for health providers and patients through reduced travel, potential for cost savings, and an opportunity to develop culturally appropriate services that are more sensitive to the needs of special populations. The uptake of telehealth has been hindered at times by clinician reluctance and policies that preclude metropolitan populations from accessing telehealth services.

Objective: This study aims to investigate if telehealth reduces health system costs compared with traditional service models and to identify the scenarios in which cost savings can be realized.

Methods: A scoping review was undertaken to meet the study aims. Initially, literature searches were conducted using broad terms for telehealth and economics to identify economic evaluation literature in telehealth. The investigators then conducted an expert focus group to identify domains where telehealth could reduce health system costs, followed by targeted literature searches for corresponding evidence.

Results: The cost analyses reviewed provided evidence that telehealth reduced costs when health system-funded travel was prevented and when telehealth mitigated the need for expensive procedural or specialist follow-up by providing competent care in a more efficient way. The expert focus group identified 4 areas of potential savings from telehealth: productivity gains, reductions in secondary care, alternate funding models, and telementoring. Telehealth demonstrated great potential for productivity gains arising from health system redesign; however, under the Australian activity-based funding, it is unlikely that these gains will result in cost savings. Secondary care use mitigation is an area of promise for telehealth; however, many studies have not demonstrated overall cost savings due to the cost of administering and monitoring telehealth systems. Alternate funding models from telehealth systems have the potential to save the health system money in situations where the consumers pay out of pocket to receive services. Telementoring has had minimal economic evaluation; however, in the long term it is likely to result in inadvertent cost savings through the upskilling of generalist and allied health clinicians.

Conclusions: Health services considering implementing telehealth should be motivated by benefits other than cost reduction. The available evidence has indicated that although telehealth provides overwhelmingly positive patient benefits and increases productivity for many services, current evidence suggests that it does not routinely reduce the cost of care delivery for the health system.

(J Med Internet Res 2020;22(10):e17298) doi: $\underline{10.2196 / 17298}$ 


\section{KEYWORDS}

cost-benefit analysis; telemedicine; review

\section{Introduction}

The sustainability of health systems is a major concern for governments worldwide. The financial viability of the health system is of particular concern, in light of both increasing costs and the increasing ratio of health expenditure to gross domestic product (GDP). For example, in Australia, in the decade to 2017, health care expenditure nearly doubled and the ratio of health expenditure to GDP increased from $8.75 \%$ to $10.28 \%$ [1]. Similarly, in the United States during the same time frame, health expenditure grew by $50 \%$ and the ratio of health expenditure to GDP increased from $15.9 \%$ to $17.9 \%$ [2]. This has catalyzed an imperative to reduce the cost of providing health care, as these increases are not sustainable long term.

Telehealth is the delivery of clinical health services using information and communication technologies to bridge the geographic separation of the clinician and consumer. Telehealth could potentially impact costs due to shorter interactions, reduced travel, economies of scale, increased revenues, or moving elements of care from clinicians to technology (eg, monitoring device) or to the patient themselves. The potential to reduce the cost of health care is one of the predominant reasons for the interest in implementing telehealth, followed closely by a desire to improve access to health care. Telehealth is often used to substitute a proportion of in-person encounters, and this substitution raises the question of a relative cost reduction.

Demonstrated cost-effective interventions may not be implemented due to budget constraints [3]. Hence, many health care organizations may be limited to implementing only telehealth interventions where cost reduction can be realized within a budgetary cycle and there is no cost increase associated with implementation. However, these programs are few, and

Figure 1. Scoping review methods.

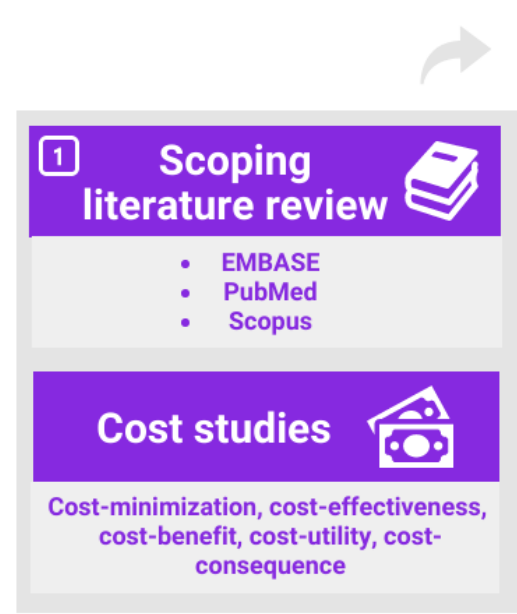

those that start successfully are not always sustainable in the long run, scalable, or transferable to other settings. Although proponents of telehealth often have projected health care savings, there is a dearth of evidence to support this view. Important questions relating to cost and sustainability remain unanswered [4].

Reviews of telehealth cost-effectiveness are often limited to one clinical specialty, service modality, or country [5-8]. Limited research has looked collectively at available evidence, and to our knowledge, none have synthesized it from the perspective of the health system. Despite the differences between international health systems, identifying and collating information regarding the cost-saving potential of telehealth is valuable.

The aims of this scoping review were twofold. First, to investigate if telehealth reduces health system costs compared with traditional service models using international evidence, and second, to identify the scenarios in which cost savings can be realized.

\section{Methods}

\section{Study Design}

The Arksey and O'Malley scoping review method was used to achieve the aims of this study [9]. This methodology involved an initial literature review, followed by an expert focus group, and finally targeted literature searches based on the focus group discussion (Figure 1) [9]. A scoping review method was chosen due to the volume of literature [10]. Reporting of the methods and results was performed in accordance with the Preferred Reporting Items for Systematic reviews and Meta-Analyses extension for Scoping Reviews (PRISMA-ScR) Checklist [11].

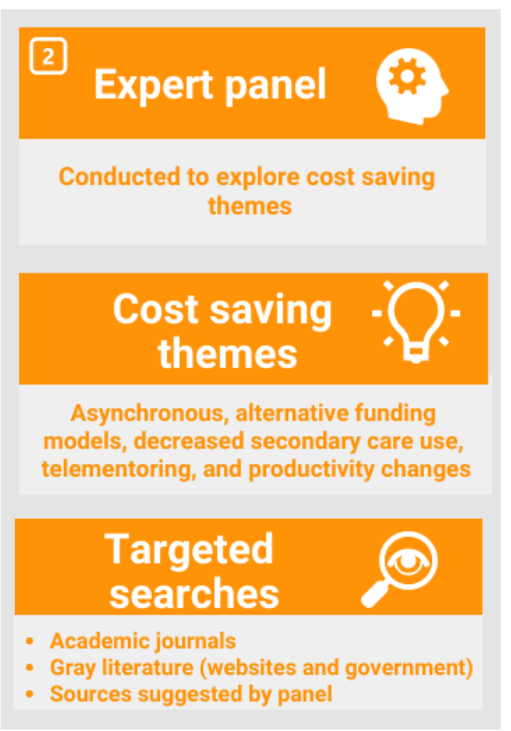




\section{Initial Literature Review (Economic Evidence)}

To identify literature reporting the results of economic evaluations in telehealth, initial literature searches were conducted using terms relating to telehealth, telemedicine, and economics. Searches were conducted using the PubMed, EMBASE, and Scopus databases. Search results were restricted to publications available in English, and no restriction was placed on the country of origin or health system model described. The scope of the review was restricted to short- to mid-term (6 months to 3 years) term and cost implications reported from the perspective of the health system payer (ie, health service or hospital). After the completion of database searches, duplicates were removed, titles and abstracts were screened by 2 authors (MT and CS), and a full-text review of articles was conducted by 3 authors (MT, LC, and CS). Included studies were categorized as cost-minimization analysis (CMA), cost-effectiveness analysis (CEA), and cost-utility analysis (CUA) studies [6,12,13]. Further descriptions of these categories are provided in Table 1.

Table 1. Description of cost analysis types.

\begin{tabular}{ll}
\hline Method & $\begin{array}{l}\text { Description } \\
\text { CMA }^{\mathrm{a}}[14]\end{array}$ \\
$\begin{array}{l}\text { CMA requires either proof or a stated assumption that the two comparators are equally effective, and therefore, the analysis only ex- } \\
\text { amines the difference in cost between the comparators. When comparing CMA, it is important to examine the items included for } \\
\text { costing for each comparator as well as the final reported result. }\end{array}$ \\
CEA $^{\mathrm{b}}[12]$ & $\begin{array}{l}\text { CEA quantifies both the costs and a measurable effect (eg, blood pressure in mm Hg or days to diagnosis) from the comparators and } \\
\text { presents them as a cost per increment of effectiveness. Due to the variety in measured effects, CEA are not easily comparable unless } \\
\text { they use the same measure for effectiveness. }\end{array}$ \\
& $\begin{array}{l}\text { CUA uses measures of cost and health-related quality of life (often expressed as a utility value) to compare interventions with usual } \\
\text { care. Although more comparable, it is important to examine not only the cost estimations but also the method of eliciting health-related } \\
\text { quality of life within each study. }\end{array}$ \\
\hline
\end{tabular}

${ }^{\mathrm{a}} \mathrm{CMA}$ : cost-minimization analysis.

${ }^{\mathrm{b}} \mathrm{CEA}$ : cost-effectiveness analysis.

${ }^{\mathrm{c}} \mathrm{CUA}$ : cost-utility analysis.

Data were extracted from the included studies by two investigators, and any disagreements in data extraction were discussed until a consensus was reached. The results were synthesized, and descriptions of systems in which telehealth reduces costs to the health system were identified and reported. All articles were quality assessed using the Consolidated Health Economic Evaluation Reporting Standards (CHEERS) [15]. CHEERS is a 24-point quality assessment tool for published economic evaluations. It includes domains to assess the reporting of relevant economic principles such as currency, discounting, time horizon, effectiveness measures, choice of outcome, assumptions, and model choice. The CMA studies were assessed according to 20 of the 24 points in the checklist; choice of health outcome, measurement of effectiveness, measurement and valuation of preference-based outcomes, and incremental costs and outcomes were not applicable. All costs were converted to 2019 US \$ to allow for ease of comparison. The synthesis of the findings was narrative.

\section{Expert Panel Focus Group}

Ethics approval to undertake the focus group was received from The University of Queensland's Human Research Ethics Committee (Approval \# 2018002428).

The framework proposed by Arksey and O'Malley [9] identifies that reviews can be enhanced by including a consultation process. To this end, investigators conducted an expert focus group to identify the domains where telehealth could reduce health system costs.

National experts in telehealth and economics were sent an invitation to attend the focus group on "How can telehealth reduce health system costs?". Experts were identified and recruited through existing relationships between the research team and the Australasian Telehealth Society who assisted with recommending individuals with both health economics and telehealth expertise. A total of 16 experts were invited to participate and 9 agreed to represent 7 different organizations. Participation was via focus group $(n=7)$ or via email and telephone with the investigators $(n=2)$.

Attendees were given the option to attend in person or via videoconference. Before attendance, invitees were emailed a discussion paper. Invitees were asked if they agreed or disagreed with the points in the discussion paper and if any additional factors should be considered. Some invitees who were unable to attend the meeting provided feedback via email or phone. Open-ended questions on the potential for cost savings arising from telehealth were used to facilitate discussion in the focus group. The discussion was recorded and notes were recorded. Topics suggested by the expert panel were synthesized and categorized under distinct topic headings (domains). These domains were used to direct further literature searches. By including the focus group consultative exercise where participants were given potential domains, it was possible to elicit more ideas on the subject matter, resulting in richer data [9].

\section{Targeted Literature Searches}

Subsequent to the focus groups, further literature searches were conducted to locate evidence on domains identified by the expert panel. Literature searches were conducted using both broad search terms and domain-specific terms to identify supporting evidence. Searches were conducted in PubMed, EMBASE, Scopus, and gray literature. Additionally, members of the expert panel contributed relevant evidence items (designated as hand 
searches). No restrictions on publication date were set during any search process. Searches were conducted from May 2018 to January 2019. Articles were omitted when the telehealth modality referenced telephone only. Search terms included, but were not limited to, telehealth, telemedicine, store-and-forward and other telehealth nomenclature, and domain-specific search terms such as secondary care or productivity. No restrictions were placed on the country of origin or the health system described in the analyses.

The level of evidence was described using the National Health and Medical Research Council guidelines [16], where, for example, I is a systematic review of randomized controlled trials (RCTs), II is an RCT, III is a comparative study with or without controls, and IV is a case series. The results of the subsequent articles identified through the targeted searches were summarized.

\section{Results}

\section{CMA}

Searches and screening identified 17 cost-minimization studies that reported their results from the perspective of the health system. Of these 17,9 studies (53\%) reported telehealth to be cost saving compared with conventional care (Figure 2), 6 studies $(35 \%)$ reported telehealth to be cost saving after a workload threshold was achieved, and 2 studies $(12 \%)$ reported telehealth to be more expensive than conventional care. The overall quality of reporting was sound, with an average score of 15 out of 20 (Table 2 ).

Figure 2. Proportion of studies identified that saved costs. CEA: cost-effectiveness analysis; CMA: cost-minimization analysis; CUA: cost-utility analysis.

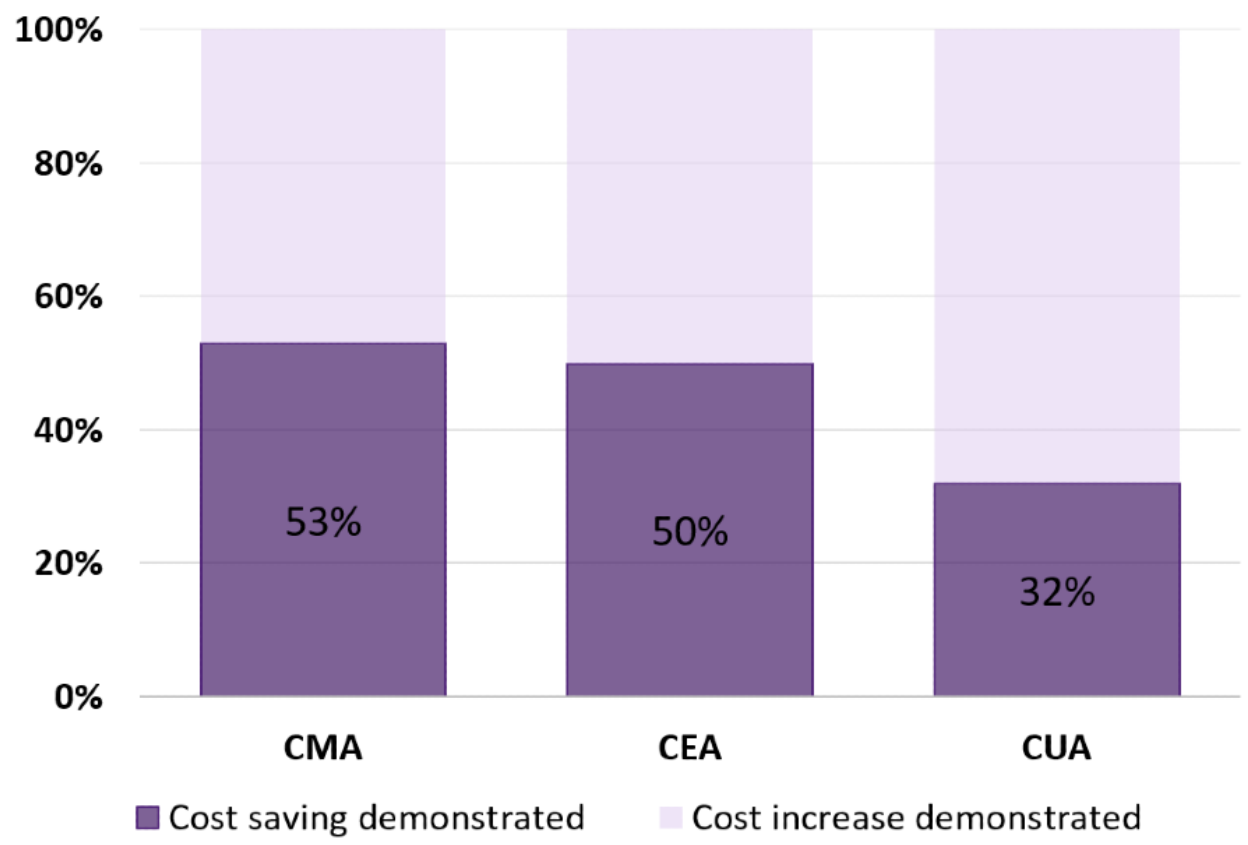


Table 2. Cost-minimization analysis demonstrating lower costs for telehealth from the perspective of the health system.

\begin{tabular}{|c|c|c|c|c|c|}
\hline Reference & $\begin{array}{l}\text { Telehealth modality and } \\
\text { clinical focus }\end{array}$ & $\begin{array}{l}\text { CHEERS }^{\mathrm{a}} \\
\text { score (out of } \\
\text { 20) }\end{array}$ & Findings in US \$ 2019 & $\begin{array}{l}\text { Initial investment in US } \\
\$ 2019\end{array}$ & $\begin{array}{l}\text { Reason for lower cost in } \\
\text { the telehealth group }\end{array}$ \\
\hline $\begin{array}{l}\text { Kovács et al } \\
(2017)[17], \\
\text { Hungary }\end{array}$ & $\begin{array}{l}\text { Store-and-forward system } \\
\text { for screening for retinopa- } \\
\text { thy of prematurity }\end{array}$ & 18 & $\begin{array}{l}\text { Cost per examination for tele- } \\
\text { health was less than in-person } \\
\text { examination. }\end{array}$ & $\begin{array}{l}\$ 199,959.03 \text { including } \\
\text { equipment and imple- } \\
\text { mentation costs }\end{array}$ & $\begin{array}{l}\text { Saved patient transport } \\
\text { costs; saved working hours }\end{array}$ \\
\hline $\begin{array}{l}\text { Buysse et al } \\
(2008)[18], \\
\text { Belgium }\end{array}$ & $\begin{array}{l}\text { Remote monitoring for } \\
\text { high-risk pregnancy replac- } \\
\text { ing extended hospital ad- } \\
\text { missions }\end{array}$ & 14 & $\begin{array}{l}\text { Cost reduction for remote } \\
\text { monitoring of } \$ 233,958 \text { per } \\
\text { year. }\end{array}$ & $\$ 15,409.17$ & $\begin{array}{l}\text { Saved admitted days. If an } \\
\text { average of } 8 \text { patients were } \\
\text { suitable for and accepted } \\
\text { remote monitoring each } \\
\text { month, an average of } 14.7 \\
\text { admitted days could be re- } \\
\text { placed by remote monitor- } \\
\text { ing }\end{array}$ \\
\hline $\begin{array}{l}\text { Armstrong et al } \\
(2007)[20] \\
\text { United States }\end{array}$ & $\begin{array}{l}\text { Store-and-forward system } \\
\text { for dermatology screening, } \\
\text { diagnosis, and triage }\end{array}$ & 15 & $\begin{array}{l}\text { Teledermatology practice had } \\
\text { an hourly operating cost of } \\
\$ 361 \text { versus } \$ 456 \text { for conven- } \\
\text { tional care }\end{array}$ & Not reported & $\begin{array}{l}\text { When the patient-end is in } \\
\text { a rural area (cheaper to } \\
\text { rent space in those clinics) }\end{array}$ \\
\hline $\begin{array}{l}\text { Smith et al } \\
(2007)[21] \text {, } \\
\text { Australia }\end{array}$ & $\begin{array}{l}\text { Pediatric videoconference } \\
\text { service for consultation re- } \\
\text { ducing travel requirements }\end{array}$ & 17 & $\begin{array}{l}\text { At caseload }>774 \text { cases } / 5 \text { years } \\
\text { telehealth is cost savings com- } \\
\text { pared with in-person; } \$ 598,203 \\
\text { saved over } 5 \text { years. }\end{array}$ & Not reported & $\begin{array}{l}\text { Saved patient transport } \\
\text { costs }\end{array}$ \\
\hline $\begin{array}{l}\text { Labiris et al } \\
(2005)[23] \\
\text { Greece }\end{array}$ & $\begin{array}{l}\text { Multispecialty videoconfer- } \\
\text { ence consultations service } \\
\text { (mainly orthopedics and } \\
\text { dermatology) in place of } \\
\text { in-person consultations }\end{array}$ & 13 & $\begin{array}{l}\text { Cost per consultation for tele- } \\
\text { health } \$ 327 \text { versus } \$ 333 \text { for } \\
\text { conventional care. }\end{array}$ & $\$ 34,356.78$ & Saved transportation costs \\
\hline $\begin{array}{l}\text { Norum et al } \\
(2005)[24] \\
\text { Norway }\end{array}$ & $\begin{array}{l}\text { Hybrid system for radio- } \\
\text { therapy involving store- } \\
\text { and-forward simulation } \\
\text { planning and remote oncol- } \\
\text { ogist supervision via } \\
\text { videoconference }\end{array}$ & 15 & $\begin{array}{l}\text { At workload }>9-12 \text { patients, } \\
\text { telehealth is less expensive } \\
\text { when patient transport by air is } \\
\text { required. }\end{array}$ & $\$ 112,115.99$ & $\begin{array}{l}\text { Avoided emergency trans- } \\
\text { fers }\end{array}$ \\
\hline $\begin{array}{l}\text { Scuffham et al } \\
(2002) \text { [25], } \\
\text { United King- } \\
\text { dom (Scotland) }\end{array}$ & $\begin{array}{l}\text { Generalist dentist videocon- } \\
\text { ference with specialist } \\
\text { dentists from a metropoli- } \\
\text { tan center reducing the } \\
\text { need for travel by patients } \\
\text { or specialists }\end{array}$ & 19 & $\begin{array}{l}\text { Teledentistry }(\$ 233) \text { is more } \\
\text { expensive compared with out- } \\
\text { reach }(\$ 156) \text { but less expensive } \\
\text { when compared in-person care } \\
(\$ 662) \text { per patient treated. }\end{array}$ & Not reported & $\begin{array}{l}\text { Saved patient travel } \\
\text { costs/subsidy }\end{array}$ \\
\hline
\end{tabular}




\begin{tabular}{|c|c|c|c|c|c|}
\hline Reference & $\begin{array}{l}\text { Telehealth modality and } \\
\text { clinical focus }\end{array}$ & $\begin{array}{l}\text { CHEERS }^{\mathrm{a}} \\
\text { score (out of } \\
\text { 20) }\end{array}$ & Findings in US \$ 2019 & $\begin{array}{l}\text { Initial investment in US } \\
\$ 2019\end{array}$ & $\begin{array}{l}\text { Reason for lower cost in } \\
\text { the telehealth group }\end{array}$ \\
\hline $\begin{array}{l}\text { Bjørvig et al } \\
(2002)[26], \\
\text { Norway }\end{array}$ & $\begin{array}{l}\text { Store-and-forward system } \\
\text { for diabetic retinopathy } \\
\text { screening }\end{array}$ & 17 & $\begin{array}{l}\text { At caseloads of }>110 \text {, telehealth } \\
\text { is cost saving. At workloads } \\
<110 \text {, telehealth is more expen- } \\
\text { sive than conventional care; at } \\
\text { very low workloads }(n=20) \text {, } \\
\text { telehealth is around } 20 \text { times } \\
\text { more expensive than conven- } \\
\text { tional care per consultation; at } \\
\text { high workloads ( } n=200) \text {, tele- } \\
\text { health costs around } 67 \% \text { of } \\
\text { conventional care per consulta- } \\
\text { tion. }\end{array}$ & Not reported & Saved patient travel \\
\hline $\begin{array}{l}\text { Harno et al } \\
(2001)[27], \\
\text { Finland }\end{array}$ & $\begin{array}{l}\text { Review and triage of ortho- } \\
\text { pedic cases via videocon- } \\
\text { ference }\end{array}$ & 12 & $\begin{array}{l}\text { Telehealth was } \$ 3954 \text { (total } \\
\text { service cost) less expensive } \\
\text { than the traditional referral } \\
\text { model. }\end{array}$ & Not reported & $\begin{array}{l}\text { Triage by } \mathrm{VC}^{\mathrm{b}} \text { decreased } \\
\text { the number of in-person } \\
\text { hospital visits }\end{array}$ \\
\hline $\begin{array}{l}\text { Bergmo et al } \\
(2000)[28] \\
\text { Norway }\end{array}$ & $\begin{array}{l}\text { Store-and-forward system } \\
\text { for dermatology screening, } \\
\text { diagnosis, and triage }\end{array}$ & 16 & $\begin{array}{l}\text { At caseload }>195 \text { patients per } \\
\text { year, telehealth }(\$ 96,042.79) \\
\text { costs less than hybrid out- } \\
\text { reach/patient travel service as } \\
\text { a whole }(\$ 179,634.98) \text {, patient } \\
\text { travel }(\$ 333,568.03) \text { or locally } \\
\text { employed dermatologists } \\
\text { ( } \$ 81,355.24) \text {; actual workload } \\
\text { was } 375 \text { patients. }\end{array}$ & $\$ 81355.24$ & $\begin{array}{l}\text { Saved patient and/or clini- } \\
\text { cian travel }\end{array}$ \\
\hline $\begin{array}{l}\text { Harno et al } \\
(2000)[29] \\
\text { Finland }\end{array}$ & $\begin{array}{l}\text { Triage of specialist cases } \\
\text { via email and/or videocon- } \\
\text { ference }\end{array}$ & 13 & $\begin{array}{l}\text { Telehealth is less expensive } \\
\text { with saving of } \$ 10,874 \text { over } 8 \\
\text { months for the service. }\end{array}$ & Not reported & $\begin{array}{l}\text { Triage by email and/or VC } \\
\text { decreased the number of } \\
\text { hospital visits }\end{array}$ \\
\hline $\begin{array}{l}\text { McCue et al } \\
\text { (1998) [30], } \\
\text { United States }\end{array}$ & $\begin{array}{l}\text { Review and triage of spe- } \\
\text { cialist cases (HIV, cardiol- } \\
\text { ogy, and oral surgery) by } \\
\text { videoconference }\end{array}$ & 13 & $\begin{array}{l}\text { Net saving of } \$ 22 \text { per consulta- } \\
\text { tion using telemedicine. }\end{array}$ & Not reported & $\begin{array}{l}\text { Main saving is from saved } \\
\text { transport }\end{array}$ \\
\hline $\begin{array}{l}\text { McCue et al } \\
\text { (1997) [31], } \\
\text { United States }\end{array}$ & $\begin{array}{l}\text { Review and triage of spe- } \\
\text { cialist cases (HIV, cardiol- } \\
\text { ogy, and oral surgery) by } \\
\text { videoconference }\end{array}$ & 11 & $\begin{array}{l}\text { Telehealth was cost saving real- } \\
\text { izing total service cost saving } \\
\text { of } \$ 24,352 \text { over the } 7 \text {-month } \\
\text { study period ( } \$ 21,700 \text { per an- } \\
\text { num) or cost per visit for tele- } \\
\text { health }(\$ 430) \text { versus convention- } \\
\text { al care }(\$ 835) \text {. }\end{array}$ & $\$ 251,995.49$ & $\begin{array}{l}\text { Transport savings and } \\
\text { medical cost savings }\end{array}$ \\
\hline
\end{tabular}

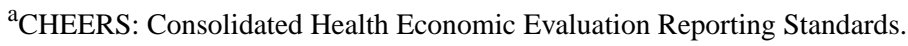

${ }^{\mathrm{b}} \mathrm{VC}$ : video consultation.

The most common situation where telehealth reduced health system costs reported in these studies was when it offsets patient or clinician travel funded or subsidized by the health system $[17,19,21,25,26,28,30,31]$. Hence, savings are most likely to be realized in the public health system, as it is unusual that other service models cover patient transport costs with the exception of the Department of Veterans Affairs. It is more likely that savings will be realized when patient travel is substituted with telehealth versus when clinician travel is substituted due to the volume, that is, saved transport cost for one clinician versus saved transport costs for many patients. One of the reviewed studies found telehealth to be less expensive than subsidized patient travel but more expensive than outreach clinics (where clinicians travel to outlying areas to provide consults) [25]. Prevention of emergency transfers was another way in which telehealth could contribute to reduced travel costs [24].
Other scenarios where potential savings can be realized include remote monitoring of high-risk pregnancies, reducing the need for in-hospital monitoring [18]. Remote monitoring in lieu of in-home visits also realized savings due to saved staff travel costs, the reduced salary of home-visit nurses, and the reduced number of hospitalizations that resulted from continual monitoring [22]. Teletriage, such as when a nurse screens a patient to determine if tertiary care is necessary, was also shown to save costs by reducing the number of hospital visits [30,31]. The two services that found telehealth to be more expensive than conventional care were due to the additional salary of a patient-end clinician (eg, general practitioner) attending a specialist consultation via videoconference $[32,33]$.

In a number of CMA studies, telehealth was found to be cost saving as compared with standard care models only after a certain caseload was exceeded, known as a threshold or 
break-even point [19,21,24-26,28]. The break-even point was when the initial investment (typically in equipment setup and staff training) was offset by realized savings later on. Many studies calculated a break-even point; however, only one study reported the payback period [17]. The payback period ranged from near immediate to 9 years after implementation [34]. The payback period could be reduced if the activity was higher and the service had the capacity for increased activity [23,31]. Cost savings for telehealth have been slow to materialize for many early adopters due to the time lag between capital investments and the broader adoption of telehealth [35]. The marginal costs of a teleconsultation were found to be less than the marginal costs of conventional consultations, indicating that telehealth is likely to benefit from economies of scale [21].

Figure 3. Cost-effectiveness studies mapped on cost-effectiveness plane

\section{CEA}

A total of 8 cost-effectiveness studies from the past 5 years that reported costs from the perspective of the health system were identified [36-43]. Of the 8 studies, 4 (50\%) were in quartile 2 of the cost-effectiveness plane (Figures 2 and 3), meaning they demonstrated cost savings and an increased or equivalent clinical effectiveness for telehealth compared with conventional in-person care. These are also known as dominant strategies and are recommended for implementation. Two of these studies reported results from a remote monitoring intervention for heart failure $[36,42]$. The remaining studies $(4 / 8,50 \%)$ were in quartile 1 of the cost-effectiveness plane, meaning increased clinical effectiveness for increased costs, requiring a value judgment to be made.

\section{Cost}

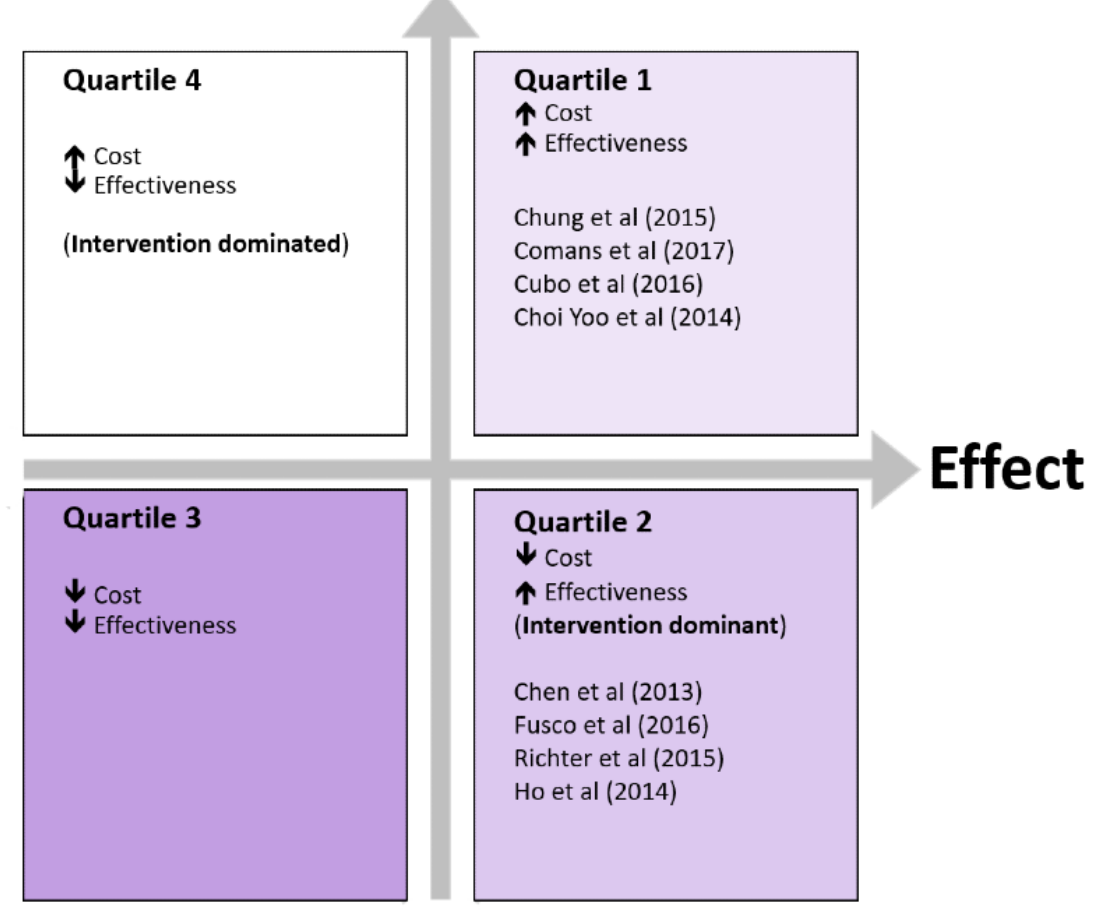

Moreover, 3 of the 4 cost-effectiveness studies in quartile 1 scored highly on quality as assessed using the CHEERS checklist [15], indicating comprehensive reporting of study results.

The telehealth services that were shown to reduce direct health system costs and be equally or more effective than their comparators were in smoking cessation [43], cardiovascular remote monitoring [36,42], and physiotherapy telerehabilitation after orthopedic surgery [41] (Table 3). Telehealth interventions for cardiovascular remote monitoring $[36,42]$ and postdischarge monitoring for neonates [44] have been shown to reduce hospital admissions, readmissions, and emergency department (ED) presentations, which have the potential to reduce overall costs to the health system $[36,42,44]$. In these studies, hospital events were used as a measure of the effectiveness of the telehealth intervention. The premise being that preventing hospital events would reduce costs for the health system if it was translated into a dollar value. 
Table 3. Summary of cost-effectiveness studies that demonstrated lower health system costs in the telehealth model.

\begin{tabular}{|c|c|c|c|c|c|c|}
\hline Reference & $\begin{array}{l}\text { Telehealth modality and } \\
\text { clinical focus }\end{array}$ & CHEERS $^{\mathrm{a}}$ score & Effect measure & $\begin{array}{l}\text { Effect improve- } \\
\text { ment with tele- } \\
\text { health? }\end{array}$ & $\begin{array}{l}\text { Reason for lower cost in } \\
\text { the telehealth group }\end{array}$ & Payback period \\
\hline $\begin{array}{l}\text { Chen et al } \\
(2013)[36] \text {, } \\
\text { Taiwan }\end{array}$ & $\begin{array}{l}\text { Remote biometric monitor- } \\
\text { ing of patients with cardio- } \\
\text { vascular disease; out-of- } \\
\text { range values trigger con- } \\
\text { tact via phone from the } \\
\text { clinical unit. }\end{array}$ & 13 & $\begin{array}{l}\text { Hospital event } \\
\text { rate }\end{array}$ & Yes & $\begin{array}{l}\text { Reduced hospitalization, } \\
\text { length of stay, and general } \\
\text { medical costs to the health } \\
\text { system when compared } \\
\text { with similar patients with- } \\
\text { out clinical monitoring and } \\
\text { support. }\end{array}$ & Not calculable \\
\hline $\begin{array}{l}\text { Ho et al } \\
\text { (2014) [42], } \\
\text { Taiwan }\end{array}$ & $\begin{array}{l}\text { Remote biometric monitor- } \\
\text { ing of patients with cardio- } \\
\text { vascular disease; out-of- } \\
\text { range values trigger con- } \\
\text { tact via phone from the } \\
\text { clinical unit. }\end{array}$ & 21 & $\begin{array}{l}\text { Hospital event } \\
\text { rate }\end{array}$ & Yes & $\begin{array}{l}\text { Reduced hospitalization, } \\
\text { length of stay, and general } \\
\text { medical costs to the health } \\
\text { system when compared } \\
\text { with similar patients with- } \\
\text { out clinical monitoring and } \\
\text { support. }\end{array}$ & $\begin{array}{l}<1 \text { year; howev- } \\
\text { er, due to the on- } \\
\text { going cost of re- } \\
\text { mote monitoring, } \\
\text { savings would } \\
\text { need to continue } \\
\text { at the same rate. }\end{array}$ \\
\hline $\begin{array}{l}\text { Fusco et al } \\
(2016)[41], \\
\text { Italy }\end{array}$ & $\begin{array}{l}\text { Physiotherapy rehabilita- } \\
\text { tion sessions delivered via } \\
\text { videoconference to pa- } \\
\text { tients after orthopedic } \\
\text { surgery. }\end{array}$ & 24 & $\begin{array}{l}\text { Range of mo- } \\
\text { tion for relevant } \\
\text { joints }\end{array}$ & Yes & $\begin{array}{l}\text { Cost savings primarily due } \\
\text { to reduced need for ambu- } \\
\text { latory government-funded } \\
\text { travel when compared with } \\
\text { in-person physiotherapy. }\end{array}$ & Not calculable \\
\hline $\begin{array}{l}\text { Richter et al } \\
(2015) \text { [43], } \\
\text { United States }\end{array}$ & $\begin{array}{l}\text { Videoconference coun- } \\
\text { selling sessions to support } \\
\text { smoking cessation provid- } \\
\text { ed by primary care clinics. }\end{array}$ & 17 & $\begin{array}{l}\text { Smoking cessa- } \\
\text { tion abstinence } \\
\text { at } 12 \text { months }\end{array}$ & Equivalent & $\begin{array}{l}\text { Compared with coun- } \\
\text { selling provided over the } \\
\text { phone, videoconference } \\
\text { sessions were shorter and } \\
\text { therefore cost less in staff } \\
\text { wages. }\end{array}$ & Not calculable \\
\hline
\end{tabular}

${ }^{\mathrm{a} C H E E R S: ~ C o n s o l i d a t e d ~ H e a l t h ~ E c o n o m i c ~ E v a l u a t i o n ~ R e p o r t i n g ~ S t a n d a r d s . ~}$

CEA studies use measures of effectiveness that reflect expected outcomes from the intervention. Many of these effects represent positive health gains and potentially medium- to long-term cost savings for the health system, such as avoided treatment of smoking-related diseases. However, the studies in which these effects have been demonstrated have not valued these gains in terms of cost.

\section{CUA}

A total of 25 cost-utility studies from the past 5 years that reported costs from the perspective of the health system and changes in health-related quality of life (HRQoL) were identified [37,40,45-65]. Of these 25 studies, 8 (32\%) studies were in quartile 2 of the health economics plane (Figures 2 and 4), as they demonstrated costs savings and increased or equivalent changes in effect as measured by HRQoL $[45,47,49,50,57,60,65,66]$.

Telehealth interventions that save money and increase quality-adjusted life years (QALYs) should be considered for implementation. As shown in Figure 5, studies in the lower right quadrant of the plane $(\mathrm{Q} 2)$ represent telehealth interventions that, when compared with usual care, represent a decrease in health care costs and a gain in QALYs. Each of these studies describes an intervention that, if implemented, could potentially save money for the health system.
The remaining studies $(17.25,68 \%)$ represent telehealth interventions that, when compared with usual care, represent an increase in health care costs and a gain in QALYs (quartile 1; Figure 4). Therefore, these interventions would only be implemented by decision makers if they were willing to pay for the relative increase in HRQoL.

All the cost-utility studies scored highly on quality as assessed using the CHEERS checklist [15], indicating the comprehensive reporting of study results.

An incidental finding of the review was that most telehealth interventions examined provided a small marginal improvement in the number of QALYs [37,40,45,46,48-68]. This small marginal change is likely due to the sensitivity of the instruments used to measure the quality of life and their ability to respond to the changes resulting from changing the service delivery model. Increases in QALYs for telehealth interventions compared with usual care were between 0.0006 and 0.12 , irrespective of the clinical area or telehealth intervention type $[37,40,45,46,48-68]$. This is below what is considered clinically meaningful. Studies conducted from a health system perspective reported cost savings between US \$32 and US \$3523. All studies were located in the dominant quartile, demonstrating that the studies that reduced costs for the health system also demonstrated either equal or increased QALYs (Figure 5; Table 4). 
Figure 4. Cost-utility studies mapped on cost-effectiveness plane.

\section{Cost}

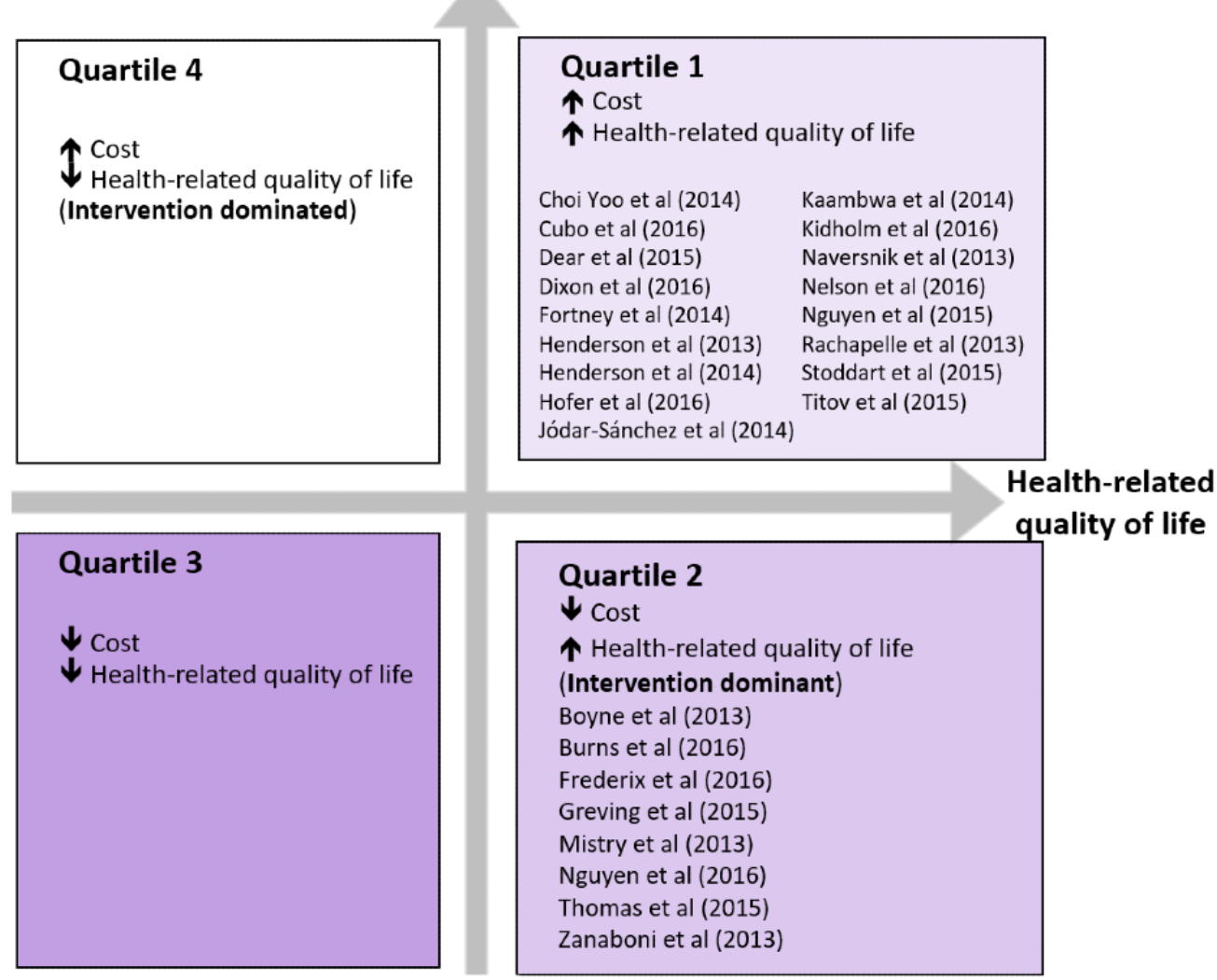

Figure 5. Quartile 2 incremental cost-utility values in 2019 US\$.

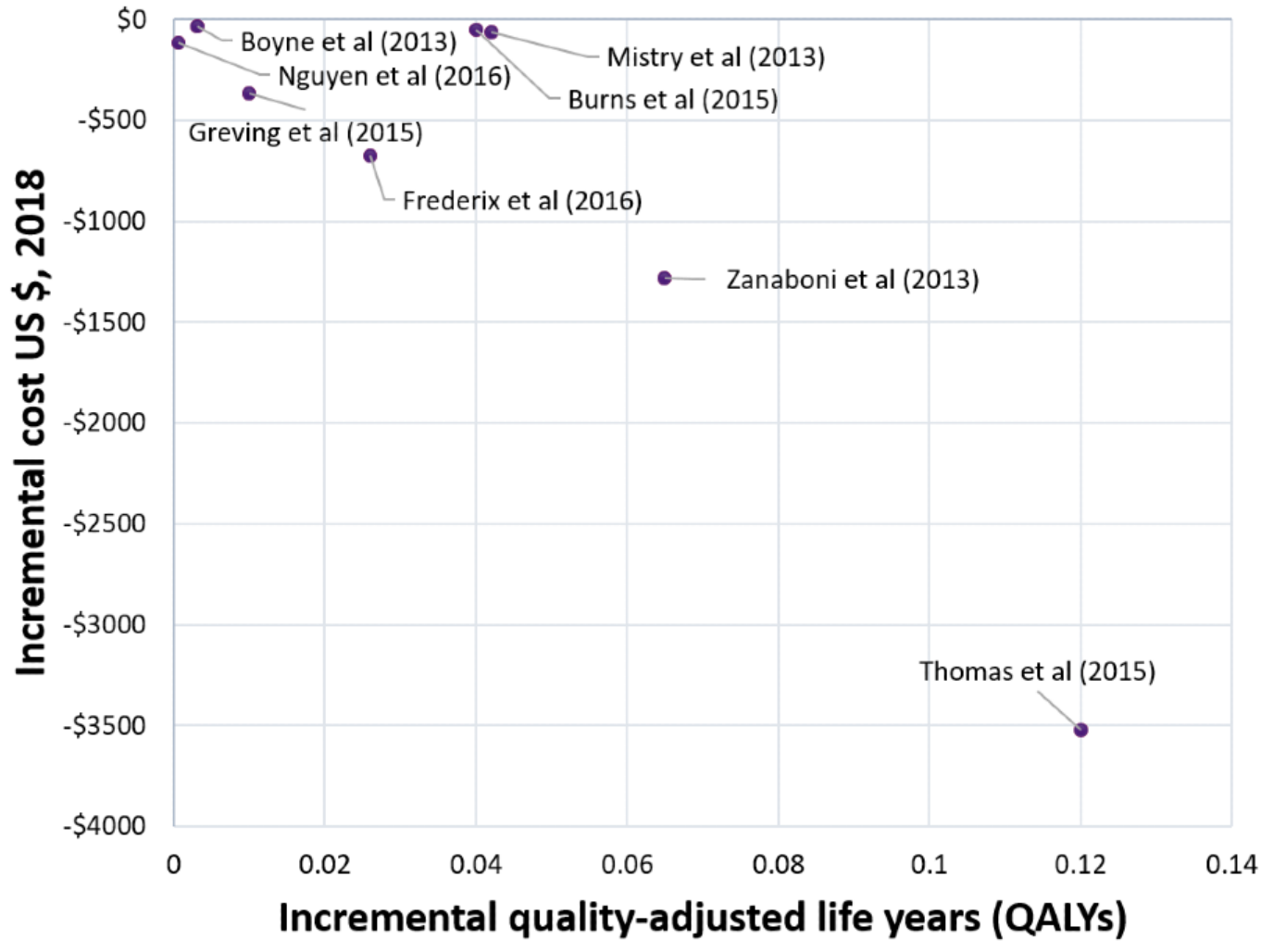


Table 4. Cost-utility analysis articles demonstrating lower cost from the perspective of the health system.

\begin{tabular}{|c|c|c|c|c|c|c|c|c|}
\hline Reference & $\begin{array}{l}\text { Telehealth modality } \\
\text { and clinical focus }\end{array}$ & $\begin{array}{l}\text { CHEERS } \\
\text { score }\end{array}$ & $\begin{array}{l}\text { Cost (tele- } \\
\text { health minus } \\
\text { usual) }\end{array}$ & $\begin{array}{l}\text { Utility (tele- } \\
\text { health minus } \\
\text { usual) }\end{array}$ & $\begin{array}{l}\text { Cost }(2019 \\
\text { US \$) }\end{array}$ & $\begin{array}{l}\text { Health-related } \\
\text { quality of life } \\
\text { tool }\end{array}$ & $\begin{array}{l}\text { Reason for lower } \\
\text { cost in the tele- } \\
\text { health group }\end{array}$ & $\begin{array}{l}\text { Payback peri- } \\
\text { od }\end{array}$ \\
\hline $\begin{array}{l}\text { Boyne et al } \\
\text { (2013) [45], } \\
\text { Netherlands }\end{array}$ & $\begin{array}{l}\text { In-home remote pa- } \\
\text { tient monitoring by } \\
\text { a nurse. Patient's re- } \\
\text { sponse to clinical } \\
\text { questions aimed at } \\
\text { identifying exacerba- } \\
\text { tion of heart failure. }\end{array}$ & 22 & $\begin{array}{l}-31 \text { (US \$, } \\
2018)\end{array}$ & 0.0031 & -31.71 & EQ5D ${ }^{b}$ & $\begin{array}{l}\text { Reduction in in- } \\
\text { person appoint- } \\
\text { ments and reduc- } \\
\text { tion in the use of } \\
\text { physiotherapy ser- } \\
\text { vices. }\end{array}$ & $\begin{array}{l}\text { Not calcula- } \\
\text { ble }\end{array}$ \\
\hline $\begin{array}{l}\text { Frederix et al } \\
\text { (2016) [49], } \\
\text { Belgium }\end{array}$ & $\begin{array}{l}\text { Remote monitoring } \\
\text { for cardiovascular } \\
\text { disease. Patients } \\
\text { wear an accelerome- } \\
\text { ter and receive feed- } \\
\text { back on their activi- } \\
\text { ty via email or SMS. }\end{array}$ & 20 & $\begin{array}{l}-564.4(\mathrm{Eu}- \\
\text { ro, 2015) }\end{array}$ & 0.026 & -676.79 & EQ5D & $\begin{array}{l}\text { Reduction in rehos- } \\
\text { pitalization costs. }\end{array}$ & $\begin{array}{l}\text { Not calcula- } \\
\text { ble }\end{array}$ \\
\hline $\begin{array}{l}\text { Greving et al } \\
\text { (2015) [50], } \\
\text { Netherlands }\end{array}$ & $\begin{array}{l}\text { Remote monitoring } \\
\text { of vascular disease } \\
\text { using patient-collect- } \\
\text { ed biometric informa- } \\
\text { tion, with feedback } \\
\text { from a remote nurse } \\
\text { monitoring their da- } \\
\text { ta. }\end{array}$ & 22 & $\begin{array}{l}-219 \text { (Euro, } \\
\text { 2009) }\end{array}$ & 0.01 & -366.54 & EQ5D & $\begin{array}{l}\text { Reduction in } \\
\text { paramedic support } \\
\text { and hospital admis- } \\
\text { sions. }\end{array}$ & $\begin{array}{l}\text { Not calcula- } \\
\text { ble }\end{array}$ \\
\hline $\begin{array}{l}\text { Mistry et al } \\
\text { (2013) [57], } \\
\text { United King- } \\
\text { dom }\end{array}$ & $\begin{array}{l}\text { Prenatal screening } \\
\text { for congenital heart } \\
\text { disease: store-and- } \\
\text { forward images and } \\
\text { videoconference } \\
\text { consultations }\end{array}$ & 23 & $\begin{array}{l}-30(\mathrm{UK} £ \\
2009-10)\end{array}$ & 0.042 & -60.1 & $\begin{array}{l}\text { Multiple litera- } \\
\text { ture sources }\end{array}$ & $\begin{array}{l}\text { Economies of scale } \\
\text { in telehealth } \\
\text { screening com- } \\
\text { pared with in-per- } \\
\text { son screening. }\end{array}$ & $\begin{array}{l}\text { Not calcula- } \\
\text { ble }\end{array}$ \\
\hline $\begin{array}{l}\text { Nguyen et al } \\
(2016)[60], \\
\text { Singapore }\end{array}$ & $\begin{array}{l}\text { Store-and-forward } \\
\text { diabetic retinopathy } \\
\text { screening. Images } \\
\text { captured by a nurse } \\
\text { reviewed off-site, } \\
\text { and the report is sent } \\
\text { to the doctor. }\end{array}$ & 20 & $\begin{array}{l}-144 \text { (Singa- } \\
\text { pore } \$, \text { not } \\
\text { specified) }\end{array}$ & 0.0006 & -114.65 & Time trade off & $\begin{array}{l}\text { Centralized image } \\
\text { examination was } \\
\text { lower cost when } \\
\text { compared with dis- } \\
\text { tributed image ex- } \\
\text { amination. Addi- } \\
\text { tionally, the triage } \\
\text { process reduced } \\
\text { unnecessary refer- } \\
\text { rals for appoint- } \\
\text { ments and proce- } \\
\text { dures. }\end{array}$ & $\begin{array}{l}\text { Not calcula- } \\
\text { ble }\end{array}$ \\
\hline $\begin{array}{l}\text { Thomas et al } \\
\text { (2015) [66], } \\
\text { United King- } \\
\text { dom }\end{array}$ & $\begin{array}{l}\text { Store-and-forward } \\
\text { ophthalmic images } \\
\text { for glaucoma } \\
\text { screening. }\end{array}$ & 22 & $\begin{array}{l}-3569.88 \\
(\text { Can } \$ \\
2014)\end{array}$ & 0.12 & -3523.28 & $\begin{array}{l}\text { Literature } \\
\text { sources [69] }\end{array}$ & $\begin{array}{l}\text { Reduction in travel } \\
\text { and associated } \\
\text { costs associated } \\
\text { with travel (direct } \\
\text { costs and staff } \\
\text { time) and staff } \\
\text { wages due to } \\
\text { shorter appoint- } \\
\text { ments. }\end{array}$ & $\begin{array}{l}1-2 \text { years for } \\
\text { one site (sav- } \\
\text { ing per pa- } \\
\text { tient is } \\
\$ 3570 \text { and } \\
\text { current annu- } \\
\text { al workload } \\
\text { is } 300 \text { pa- } \\
\text { tients). }\end{array}$ \\
\hline $\begin{array}{l}\text { Zanaboni et al } \\
\text { (2013) [65], } \\
\text { Italy }\end{array}$ & $\begin{array}{l}\text { Remote monitoring } \\
\text { of biometric data } \\
\text { from an implanted } \\
\text { device to identify } \\
\text { heart failure exacer- } \\
\text { bations. }\end{array}$ & 19 & $\begin{array}{l}-888.1(\mathrm{Eu}- \\
\text { ro, 2010) }\end{array}$ & 0.065 & -1280.46 & EQ-5D ${ }^{b}$ & $\begin{array}{l}\text { Substituting in- } \\
\text { person clinic visits } \\
\text { with lower cost } \\
\text { virtual consults, } \\
\text { and reduction in } \\
\text { the emergency de- } \\
\text { partment and ur- } \\
\text { gent clinic visits. }\end{array}$ & 1-2 years \\
\hline
\end{tabular}




\begin{tabular}{|c|c|c|c|c|c|c|c|c|}
\hline Reference & $\begin{array}{l}\text { Telehealth modality } \\
\text { and clinical focus }\end{array}$ & $\begin{array}{l}\text { CHEERS }^{\mathrm{a}} \\
\text { score }\end{array}$ & $\begin{array}{l}\text { Cost (tele- } \\
\text { health minus } \\
\text { usual) }\end{array}$ & $\begin{array}{l}\text { Utility (tele- } \\
\text { health minus } \\
\text { usual) }\end{array}$ & $\begin{array}{l}\text { Cost }(2019 \\
\text { US \$) }\end{array}$ & $\begin{array}{l}\text { Health-related } \\
\text { quality of life } \\
\text { tool }\end{array}$ & $\begin{array}{l}\text { Reason for lower } \\
\text { cost in the tele- } \\
\text { health group }\end{array}$ & $\begin{array}{l}\text { Payback peri- } \\
\text { od }\end{array}$ \\
\hline
\end{tabular}

${ }^{\mathrm{a} C H E E R S}$ : Consolidated Health Economic Evaluation Reporting Standards

${ }^{\mathrm{b}}$ EQ5D: EuroQol five dimensions

\section{Focus Group}

The expert panel focus group ran for 1 hour, and 7 experts attended from 5 institutions. Two further experts from 2 different organizations were unable to attend and provided input via email or telephone instead. They covered telehealth expertise in academic research, health service provision, and economics.
Seven experts who were contacted did not respond. The videoconference session was recorded so that the investigators could review the comments during the writing of this report.

At the conclusion of the expert panel, the telehealth domains where health system costs could potentially be reduced were finalized. These domains are listed in Table 5.

Table 5. Domains identified from expert feedback.

\begin{tabular}{lll}
\hline Domain & Description & Level of evidence [16] \\
\hline $\begin{array}{l}\text { Productivity gains } \\
\begin{array}{l}\text { Secondary care resource } \\
\text { use }\end{array}\end{array}$ & $\begin{array}{l}\text { Optimization of staff time leading to productivity gains. } \\
\text { There is potential for telehealth to reduce secondary care resource (eg, emergency } \\
\text { department presentation, hospitalization, and medical imaging) use with associated } \\
\text { costs savings. }\end{array}$ & Level I-III \\
$\begin{array}{l}\text { Alternative funding } \\
\text { models }\end{array}$ & $\begin{array}{l}\text { The commercialization of telehealth has resulted in direct-to-consumer models of care } \\
\text { where patients pay for their services directly, rather than accessing subsidized care. }\end{array}$ & $\begin{array}{l}\text { Evidence in this emerging field } \\
\text { does not map to any NHMRC } \\
\text { levels }\end{array}$ \\
Telementoring & $\begin{array}{l}\text { Telementoring of primary care can increase the skill level of clinicians, thereby reducing } \\
\text { future referrals to specialists for similar cases. }\end{array}$ & $\begin{array}{l}\text { Evidence in this emerging field } \\
\text { does not map to any NHMRC lev- } \\
\text { els }\end{array}$ \\
\hline
\end{tabular}

${ }^{\mathrm{a}}$ NHMRC: National Health and Medical Research Council.

\section{Productivity Gains}

The first domain identified by the expert focus group was productivity gains, which is when the productivity of a system is increased, cost savings can be realized due to the increased capacity of the system. In the case of telehealth, it is possible that a greater volume of patients can be managed with similar resources, which increases the productivity of the health system and reduces the marginal cost per patient. Evidence of increasing physician productivity with the use of telehealth exists in various other forms, including case control, RCT, CMA, and case series. Telehealth has the potential to increase health system productivity through a number of mechanisms, including reducing travel, reducing consultation time, and substituting for in-person service modalities.

\section{Reduction in Travel}

When telehealth reduces or eliminates clinician travel time because service delivery occurs through videoconference, the clinicians' productivity is increased because they can see more patients in the same time frame. One program in the United States that implemented a videoconference telehealth model to replace home visits found that nurses' caseload capacity more than doubled and over 14 months, 43,560 driving minutes were saved [70]. Similarly, an economic evaluation of The Northern Health Authority in Canada found that telehealth sessions replacing in-person sessions saved the health service Can $\$ 65,520$ (US $\$ 49,584.14$ ) in annual travel costs associated with clinical sessions [71].

\section{Change in Consultation Time}

When in-person consultations are substituted for a video consultation of a shorter duration, the clinic has an increased capacity to see more patients in the same amount of time. 
Studies that compared videoconference consultation time with in-person consultation time reported disparate results, finding that videoconference was less time efficient, equally time efficient, and more time efficient. One study reported that teleconsultations may take more time than in-person appointments in cases such as assessing injuries by video as opposed to on-site [72]. Four studies reported that videoconference was equally as time efficient as in-person consultations. These included studies reporting results from studies examining services in dermatology [73], prostate cancer [74], pulmonary medicine [75], and orthopedics [76]. However, there is also evidence to suggest that videoconference consultations were more time efficient, as shown in a dermatology service from Norway [76,77] and a diabetes, antenatal, and cancer care service by Greenhalgh et al $[77,78]$. The small gains in clinician efficiency may be offset by increased administrative overhead associated with telehealth compared with in-person consultations [79].

\section{Consultation Mode Substitution}

If in-person consultations are substituted for alternate consultation modalities such as asynchronous consultations (store-and-forward or virtual), productivity is often increased as more patients are able to be managed simultaneously [5,27,80-83]. Asynchronous consultations are when the patient and clinician are not localized to the same time point. Asynchronous consultations, therefore, represent a mechanism by which the overall productivity of the health system can be improved. For instance, a specialist may be able to review clinical notes and images for a large group of patients in lesser time than it would take them to see all the patients in person [29]. Such services include dermatology consultations where either a patient or primary carer sends clinical information and dermoscopic or regular images for review; patients are then either returned to their primary care, discharged from care, or scheduled for an in-person dermatologist appointment $[5,80,81,84]$. Consultations are typically quicker when they are asynchronous, for example, one study found that an asynchronous dermatology consultation takes $4 \mathrm{~min}$, which is one tenth of the time for a traditional consultation [85]. This increases the system throughput and can optimize both waitlists and patient prioritization. Similarly, a case-control study showed that clinicians who used a web-based messaging platform to manage patients had a $10 \%$ increase in productivity compared with those who conducted in-person consultations and followed up with phone calls [86]. The increase in productivity resulted in an additional 2.54 patients per day being seen, which in a fixed funding model would lead to a reduction in marginal cost per patient.

A study by Liddy et al [82] demonstrated that when community clinicians could send asynchronous consultations to specialists, compared with the previous system where $50 \%$ of these cases would have resulted in the referral of the patient for an in-person consultation, only $18 \%$ of cases required an in-person consultation. Another recent study showed that $68 \%$ of in-person appointments were unnecessary when an asynchronous teledermatology triage model was used $[86,87]$.

\section{Failure to Attend}

When patients fail to attend appointments, it costs the health system money by increasing the marginal cost of all appointments in that service. Additionally, it represents an opportunity cost as an alternative patient has to forego an appointment. One study postulated that when patients are treated by primary care providers in their own community, the chance of them missing the appointment may be less likely than if they were traveling to a hub site further from where they live [88].

\section{Payment Model}

The reimbursement model needs to be considered when examining the reported productivity increases, as the marginal cost per patient will only decrease if the service provision costs remain constant as patient volume increases. A more productive clinician who is able to manage a larger number of patients will increase the cost to the health system under activity-based funding, fee-for-service, or a capitation reimbursement model. However, when clinician costs are fixed (eg, salaried), increased productivity will reduce the marginal cost per patient.

\section{Summary}

Telehealth can increase clinician productivity, thereby increasing the volume of patients that can be managed by a health service. Assuming fixed costs, this can result in a reduced marginal cost per patient overall. Telehealth can enable a clinician to convert travel time to clinical time, thereby improving productivity. However, when a clinician does not have to travel, substituting in-person consultations with video consultations is unlikely to have a major impact on consultation time and resultant productivity and savings. Furthermore, the increased administrative overhead for scheduling video consultations may counteract any gains. Increased productivity is more likely to be achieved in store-and-forward and virtual consultations. Realizing savings from productivity gains is dependent on the funding model. Increased productivity under activity-based funding, fee-for-service, or a capitation reimbursement model will increase the cost for the health system.

\section{Secondary Care Resource Use}

Secondary care involves services provided by specialist or tertiary centers and includes hospital admissions, specialist outpatient visits, and ED presentations. Avoidance of secondary care in favor of other methods of care has the potential to reduce health system costs [89]. The evidence was from RCTs, case-control prospective and observational studies, and reviews of health services. Most of the studies, except the CMA conducted by Pare et al [22], reported economic findings as a secondary result. This resulted in moderate quality studies examining changes in secondary care usage related to telehealth, but a level of extrapolation from the results was needed to interpret cost savings. The use of telehealth to reduce secondary care may be realized through a number of scenarios, including remote monitoring, hospital avoidance, and triage.

\section{Remote Monitoring}

Remote monitoring, or telemonitoring, is an established modality of telehealth where patients are monitored from a distance. Remote monitoring is used most often to monitor chronic 
diseases (eg, hypertension, cardiac disease, pulmonary disease, and diabetes). Remote monitoring involves the continual in-home recording of targeted biometric readings (eg, blood pressure, glucose levels, weight, and spirometry) and in some services, patient-reported measures (eg, level of breathlessness). The readings are subsequently transmitted to a clinician for review. Remote monitoring may be performed in conjunction with in-person consults [7] or video or audio conference consults [90]. The aim of remote monitoring is the early detection and management of exacerbations, which may obviate an ED presentation or hospital admission.

Findings on secondary care usage resulting from remote monitoring usage are mixed. Telemonitoring in France, the United Kingdom, the United States, and Australia have demonstrated a reduction in hospitalization resulting directly from the use of remote monitoring compared with patients who were not monitored remotely [91-94]. In the UK trial, remote monitoring of patients with chronic disease (eg chronic obstructive pulmonary disorder, diabetes, or heart failure) was associated with an overall reduction in hospital admissions [93]. These results were consistent at three trial sites using a variety of remote monitoring technologies, such as pulse oximeters, glucometers, and weighing scales [93]. Similarly, in the United States, when patient vital signs were transmitted to a nurse for review and intervention, rates of acute care hospitalization (1.7 vs 4.4 per 1000 home health days) and ED presentations (1.9 vs 5.3 per 1000 patient days) reduced [94]. In Australia, the study by Celler et al [92] found that when using remote monitoring, clinicians were able to predict and avoid 53\% of admissions by conducting a low-cost intervention in a timely manner. Remote monitoring has been shown to reduce not only a patient's presentation to the hospital but also their length of stay once admitted. This may be due to the confidence remote monitoring gives clinicians, that when they discharge a patient, the patient is still under observation should any acute needs arise. For example, a hospital in Belgium monitored high-risk mothers at home instead of keeping them in the hospital [18]. There are, however, some studies that demonstrate in certain scenarios telemonitoring does not reduce secondary care use but, in fact, can increase secondary care usage $[83,95]$.

When reduced secondary care usage is achieved, it would logically convert into the reduced cost for the health system. However, the economic analysis of remote monitoring does not conclusively report savings. Some studies report significant cost savings $[18,22,90,96]$. Other studies have found very small savings. Lew et al [97] found that for some patient groups, admission costs only reduced from US $\$ 10,835$ to US $\$ 10,678$. In the Whole System Demonstrator trial, cost savings amounted to a modest $£ 188$ per person per year [93]. Other studies report that remote monitoring resulted in equivalent or greater costs [97,98]. Many economic analyses of remote monitoring only report direct health care costs and do not report overall program costs such as amortization of equipment costs or the cost of running the service [7]. Other contextual factors may also influence the findings. For example, monitoring a single vital sign is less costly than monitoring multiple signs, and remote monitoring of hypertension and congestive cardiac failure is less costly than remote monitoring of respiratory diseases [7].

\section{Hospital Avoidance}

Telehealth can be used to facilitate hospital avoidance, which can potentially reduce costs, particularly in reducing ED presentations. Emergency Medical Services in Houston, United States, implemented a system where after an ambulance was dispatched and before the patient was transported to the ED, they conducted a videoconference with a physician [99]. Where appropriate, the patient was directed to primary care, the ED via a taxi or personal travel means or via ambulance as necessary [99]. Transports to the ED by ambulance were significantly reduced by over $50 \%$, and the team was back in service for the next call 44 min faster [99]. A similar service in the context of residential aged care reported that the use of telehealth before transportation reduced ED presentations by 28\% [100]. However, neither of these studies quantified savings.

\section{Triage}

Similar to findings (previously described) from the economic analyses reviewed, a recent review identified that teletriage could reduce a substantial number of unnecessary specialist outpatient appointments. The review found that for dermatology, the reported rate of avoided in-person appointments ranged from $38 \%$ to $88 \%$ and for ophthalmology ranged from $16 \%$ to $48 \%$. Single studies for ear, nose, and throat and vascular surgery/wound care reported an $89 \%$ and $18 \%$ reduction in in-person appointments, respectively [101]. However, no study has quantified the potential cost savings.

\section{Summary}

Telehealth appears to have the potential to reduce secondary health care usage. However, while many studies demonstrate a reduction in secondary care, there are limited studies that quantify cost savings for the health system payer. Cost analyses do not always consider the overall costs of telehealth interventions and instead only compare the costs associated with direct health care utilization. A more accurate assessment would include program costs such as amortization of equipment costs or the cost of running the service. The use of telehealth for triage can reduce unnecessary specialist outpatient appointments. Although this would logically reduce costs for a health care provider, no study has quantified cost savings.

\section{Alternative Funding Models}

Direct-to-consumer telehealth services are often funded by consumer payments. User pays funding models can potentially reduce costs, particularly if they substitute for government-funded or government-subsidized health services. Hence, savings to the health system are based on the assumption that individuals who access direct-to-consumer services would have otherwise accessed an equivalent health system service if the telehealth option was unavailable to them. In Australia, very few direct-to-consumer services are eligible for reimbursement from the Medicare Benefits Scheme. Consumers accessing these services are required to pay the full service fee as an out-of-pocket cost. This leads to cost savings for the government when consumers access these services instead of Medicare-funded services. Users may be willing to pay a higher out-of-pocket cost for these services because they offer elements that they value, for instance, either convenience or timely 
specialist access. However, due to the convenience of telehealth services, there is a risk that direct-to-consumer services may not reduce health system usage, but rather may increase overall health service utilization and costs to the health system [102]. That is, individuals who would not normally use health services may begin accessing telehealth services because of the convenience provided by the direct-to-consumer model. When these individuals are referred to a health system service provider or given a Pharmaceutical Benefits Scheme reimbursed prescription, they increase service utilization and costs to the overall health system.

There is limited academic literature that reports on savings to the health system from direct-to-consumer telehealth. Examples of commercial direct-to-consumer telehealth models include Qoctor (previously called DrSicknote), which is an Australian web-based general practitioner service. Qoctor provides a range of general practitioner services through their website, including medical certificates, prescriptions, and specialist referral letters. In January 2019, Qoctor reported \$1,040,566 in saved costs to Medicare to date by diverting appropriate patients from standard general practitioner clinics [103]. A further example is iDoc24, where consumers capture images of skin lesions (eg, a mole), transmit the image to a dermatologist, and receive a diagnosis within 24 hours [104].

\section{Summary}

At this stage, it is difficult to quantify the cost outcomes of funding models where a consumer pays out of pocket for a commercial telehealth service. Most information is reported by the companies themselves and not through research studies. Assuming that individuals who choose to access commercial telehealth services would have instead accessed government-funded services, commercial services can reduce health system costs. As these funding models are still new, it is difficult to quantify the effect or anticipate all consequences.

\section{Telementoring}

Deferring treatment to less qualified and, therefore, less expensive staff could potentially result in reduced health system costs. This can be facilitated by telementoring. Arguably, the most well-known telementoring program is the Project Extension for Community Healthcare Outcomes (Project ECHO), a model that was started in the United States but has been adopted and practiced internationally [105]. Using this model, primary care staff are upskilled using videoconference sessions with specialists in the form of weekly telementoring sessions. During these sessions, primary care providers can present cases and receive specialist advice on diagnosis, management, and treatment for their patients.

Although telementoring was identified by the focus group as a way to potentially reduce costs, limited evidence was found to support this view. A pre- and poststudy found that telementoring in the context of geriatric mental health resulted in a small reduction in per-patient cost when medication, specialist outpatient visits, hospitalization, and ED visits were quantified from insurance claim data [106]. Although overall costs were reduced, a subanalysis did reveal increased costs resulting from an increase in antipsychotic medication prescriptions. The time horizon for reported cost reduction was 6 months. The cost of setting up and running the telementoring was not considered in this analysis.

Project ECHO, a program that provides telementoring for primary care physicians, for the management of hepatitis $\mathrm{C}$, was found to be cost-effective with an incremental cost-effectiveness ratio (ICER) of US \$10,351 per QALY [107]. This would indicate that telementoring for hepatitis $\mathrm{C}$ will increase costs to the health system but has the potential to increase population-related quality of life.

From another perspective, savings to the health system as a result of telementoring may be realized in the retention of staff and patients at remote medical practices [88].

\section{Summary}

There is limited evidence due to only a very small number of studies analyzing the costs of telementoring. Telementoring can potentially reduce health system costs in both the short term and over a longer time horizon. However, at present, evidence to support this is lacking.

\section{Discussion}

\section{Principal Findings}

Telehealth was shown to reduce costs to the health system in the short to medium term in $53 \%$ of CMA, $50 \%$ of CEA, and $32 \%$ of CUA studies reviewed. The predominant reason for reduced costs was when the health system funded travel and either patient or clinician travel was reduced or avoided. In the remaining studies (not reviewed in detail here), telehealth increased costs but was also shown to improve care [37-40,42-44,46,48,51,52,54-56,58,59,61-64]. For example, evidence indicates that remote patient monitoring is currently a poor cost minimizer; however, it is very effective for improving overall health and reducing morbidity and hospitalization.

The models of the care and the contexts in which telehealth is used are heterogeneous. The question as to whether telehealth decreases the cost of health care delivery is complex, as are all economic evaluations in telehealth [7]. There are many compounding factors to consider, for example, the modality (real-time videoconferencing, remote patient monitoring, and store-and-forward) of telehealth used or the way telehealth consultations are remunerated. In Australia, Medicare reimburses provider telehealth consultations at $150 \%$ of an equivalent in-person consultation [108]. Furthermore, reimbursement for telehealth in Australia under Medicare and activity-based funding have both provider and patient-end payments, automatically making telehealth more expensive than conventional care. Although in the United States, state-by-state reimbursement under Medicaid means a telehealth consultation may be reimbursed at a lower or equal rate to an equivalent in-person consultation.

By improving accessibility, telehealth may also increase the cost of providing health care as populations served by traditional models of care who had limited or no access to care can now access services. Further, by improving the convenience of 
access, there is potential for excess use [109,110]. Furthermore, the potential for telehealth to become adjunctive to traditional in-person care (rather than substitutive) also increases the potential for increasing use and associated costs.

Telehealth is not implemented at scale in some jurisdictions (eg, Australia) [79,111], which may impact the ability to reduce costs. The marginal cost or average cost of a telehealth consultation was found to be less than an equivalent in-person consultation in a number of studies [19,32]. However, costs of running the telehealth service remained higher than the equivalent in-person service until a threshold number of consultations was reached. A threshold number of examinations required is necessary to counteract the implementation costs of telehealth, including technology and project costs. Telehealth technology costs are decreasing. Video conference equipment costs are reducing with a move from room-based systems to consumer videoconferencing platforms. A similar cost decrease of remote monitoring equipment and resultant cost decrease in remote monitoring costs per patient per year has also been reported [7]. Future studies may find a reduction in both the threshold number of examinations and the payback period resulting from a decrease in technology costs.

\section{Implications for Practice}

Many telehealth services do not result in short- to medium-term savings. For this reason, health services considering implementing telehealth should be motivated by the benefits of telehealth other than cost reduction and recognize that implementing telehealth will require recurrent investment costs.

Asynchronous consultations are likely to reduce consultation time compared with equivalent in-person consultations, thereby improving clinician productivity. There is potential to increase the cost to the health system under fee-for-service models; hence, reimbursement for consultations where the patient is not present needs to account for increased productivity. One such example is a recent application from the Australasian College of Dermatologists for Medicare funding for store-and-forward dermatology, which sought a lower reimbursement than in-person consultations [112].

\section{Implications for Research}

This study has identified a number of opportunities for future research. Many of the reviewed economic analyses of telehealth are older than 10 years. Contemporary economic analysis of telehealth is needed to consider changes in technology costs. Our study has also identified a gap in economic analyses related to telementoring. Furthermore, the use of telehealth to triage referrals in dermatology, wound care, otolaryngology, and ophthalmology can be effective in reducing unnecessary specialist outpatient appointments; however, there are no published cost analyses. Additionally, the use of remote patient monitoring has been shown to reduce costs and increase costs in different contexts. Many remote monitoring studies did not report overall cost savings (eg, the cost of implementing and running the service). Analyses of remote monitoring services need to include overall costs rather than direct health costs alone to determine if remote patient monitoring reduces system costs.

\section{Limitations}

Positive reporting bias is likely to result in an increased number of studies reporting cost-effectiveness and cost-minimization of telehealth. Savings on travel resulting from telehealth are more beneficial to the health system in countries such as Australia. The large geographical areas and a public health system that funds travel favor such contexts. For this reason, the findings of cost savings are rarely generalizable. Additionally, it is unlikely that the studies examined were statistically powered for economic findings, as it is routine practice to power for the primary clinical outcome, meaning economic outcomes may not be precise. The aim of this study was to identify short- to medium-term cost savings; therefore, a further limitation of this study is that studies examining the long-term cost impact of telehealth interventions were not included.

\section{Conclusions}

This study aimed to determine whether telehealth has the potential to improve the sustainability of health systems by reducing costs. Telehealth was shown to reduce costs to the health system in the short to medium term in 53\%, 50\%, and $32 \%$ of the cost-minimization, cost-effectiveness, and cost-utility studies reviewed, respectively. The predominant reason for reduced costs was when the health system-funded travel (patient or clinician) was reduced or avoided. In the remaining studies, telehealth increased costs, albeit with improved care.

The expert focus group identified 4 areas of potential savings from telehealth: productivity gains, reductions in secondary care use, emerging alternate funding models for care provision, and savings resulting from telementoring effects. Telehealth can increase clinician productivity when it is used to convert travel time to clinical time. In terms of consultation time, there are unlikely to be productivity gains when substituting an in-person consultation with a video consultation. The use of asynchronous consultations as a substitute for in-person consultations is more likely to increase productivity by reducing consultation time. However, under activity-based funding mechanisms, there is a likelihood that these productivity gains could result in cost increases.

Mitigation of secondary care through remote patient monitoring, teletriage, and hospital avoidance has the potential to reduce costs to the provider. However, there is currently a lack of economic evidence to support this. Similarly, telementoring has scant economic evaluations to demonstrate cost savings.

Alternate funding models from telehealth systems have the potential to save the health system money in situations where the consumers pay fully out of pocket to receive services, thereby mitigating the cost to the health system. The convenience of telehealth may influence consumers to pay out-of-pocket fees. This may be considered cost-shifting as opposed to cost saving.

The available evidence has indicated that telehealth does not always reduce the cost of care from the perspective of the health system in the short to medium term. Health services considering implementing telehealth should be motivated by benefits other than cost reduction. 


\section{Acknowledgments}

This research was conducted for the NHMRC Partnership Centre for Health System Sustainability (Grant ID \#: 9100002) administered by the Australian Institute of Health Innovation, Macquarie University. Along with the NHMRC, the funding partners in this research collaboration are: The Bupa Health Foundation; NSW Ministry of Health; Department of Health, WA; and The University of Notre Dame Australia. Their generous support is gratefully acknowledged.

While the NHMRC, The Bupa Health Foundation, NSW Ministry of Health, Department of Health, WA and The University of Notre Dame Australia, have provided in-kind and financial support for this research, they have not reviewed the content and are not responsible for any injury, loss or damage however arising from the use of, or reliance on, the information provided herein. The published material is solely the responsibility of the authors and does not reflect the views of the NHMRC or its funding partners

\section{Conflicts of Interest}

None declared.

\section{References}

1. Australian Institute of Health and Welfare. Health expenditure Australia 2016-17. AIHW. Canberra: Australian Government; 2018 Sep 28. URL: https://www.aihw.gov.au/reports/health-welfare-expenditure/health-expenditure-australia-2016-17/ contents/data-visualisation [accessed 2018-12-31] [WebCite Cache ID www.aihw.gov.au/reports/health-welfare-expenditure/health-expenditure-australia-2016-17/contents/data-visualisation]

2. Centers for Medicare and Medicaid Services. National Health Expenditure Data. CMS. 2018. URL: https://www.cms.gov/ Research-Statistics-Data-and-Systems/Statistics-Trends-and-Reports/NationalHealthExpendData/

NationalHealthAccountsHistorical.html [accessed 2019-11-26]

3. Bilinski A, Neumann P, Cohen J, Thorat T, McDaniel K, Salomon JA. When cost-effective interventions are unaffordable: integrating cost-effectiveness and budget impact in priority setting for global health programs. PLoS Med 2017 Oct;14(10):e1002397 [FREE Full text] [doi: 10.1371/journal.pmed.1002397] [Medline: 28968399]

4. Agha Z, Weinstein RS, Dunn BE. Cost minimization analysis of telepathology. Am J Clin Pathol 1999 Oct;112(4):470-478. [doi: 10.1093/ajcp/112.4.470] [Medline: 10510670]

5. Snoswell C, Finnane A, Janda M, Soyer HP, Whitty JA. Cost-effectiveness of store-and-forward teledermatology: a systematic review. JAMA Dermatol 2016 Jun 01;152(6):702-708. [doi: 10.1001/jamadermatol.2016.0525] [Medline: 27074289]

6. Bergmo TS. Using QALYs in telehealth evaluations: a systematic review of methodology and transparency. BMC Health Serv Res 2014 Aug 3;14:332 [FREE Full text] [doi: 10.1186/1472-6963-14-332] [Medline: 25086443]

7. Peretz D, Arnaert A, Ponzoni NN. Determining the cost of implementing and operating a remote patient monitoring programme for the elderly with chronic conditions: a systematic review of economic evaluations. J Telemed Telecare 2018 Jan;24(1):13-21. [doi: 10.1177/1357633X16669239] [Medline: 27650163]

8. de la Torre-Díez I, López-Coronado M, Vaca C, Aguado JS, de Castro C. Cost-utility and cost-effectiveness studies of telemedicine, electronic, and mobile health systems in the literature: a systematic review. Telemed J E Health 2015 Feb;21(2):81-85 [FREE Full text] [doi: 10.1089/tmj.2014.0053] [Medline: 25474190]

9. Arksey H, O'Malley L. Scoping studies: towards a methodological framework. Int J Soc Res Methodol 2005 Feb 20;8(1):19-32 [FREE Full text] [doi: 10.1080/1364557032000119616]

10. Levac D, Colquhoun H, O'Brien KK. Scoping studies: advancing the methodology. Implement Sci 2010 Sep 20;5:69 [FREE Full text] [doi: 10.1186/1748-5908-5-69] [Medline: 20854677]

11. Tricco AC, Lillie E, Zarin W, O'Brien KK, Colquhoun H, Levac D, et al. PRISMA extension for scoping reviews (PRISMA-ScR): checklist and explanation. Ann Intern Med 2018 Oct 2;169(7):467-473. [doi: 10.7326/M18-0850] [Medline: $\underline{30178033}$ ]

12. Drummond M, Sculpher M, Claxton K, Stoddart G, Torrance G. Methods for the economic evaluation of health care programmes. New York: Oxford University Press; 2015.

13. Snoswell C, Smith AC, Scuffham PA, Whitty JA. Economic evaluation strategies in telehealth: obtaining a more holistic valuation of telehealth interventions. J Telemed Telecare 2016 Oct 27;23(9):792-796. [doi: 10.1177/1357633x16671407] [Medline: 27789615]

14. Robinson R. Costs and cost-minimisation analysis. Br Med J 1993 Sep 18;307(6906):726-728 [FREE Full text] [doi: 10.1136/bmj.307.6906.726] [Medline: $\underline{8401098]}$

15. Husereau D, Drummond M, Petrou S, Carswell C, Moher D, Greenberg D, CHEERS Task Force. Consolidated health economic evaluation reporting standards (CHEERS) statement. Cost Eff Resour Alloc 2013 Mar 25;11(1):6 [FREE Full text] [doi: 10.1186/1478-7547-11-6] [Medline: 23531194] 
16. Merlin T, Weston A, Tooher R. Extending an evidence hierarchy to include topics other than treatment: revising the Australian 'levels of evidence'. BMC Med Res Methodol 2009 Jun 11;9:34 [FREE Full text] [doi: 10.1186/1471-2288-9-34] [Medline: 19519887]

17. Kovács G, Somogyvári Z, Maka E, Nagyjánosi L. Bedside ROP screening and telemedicine interpretation integrated to a neonatal transport system: economic aspects and return on investment analysis. Early Hum Dev 2017;106-107:1-5. [doi: 10.1016/j.earlhumdev.2017.01.007] [Medline: 28171806]

18. Buysse H, De Moor G, Van Maele G, Baert E, Thienpont G, Temmerman M. Cost-effectiveness of telemonitoring for high-risk pregnant women. Int J Med Inform 2008 Jul;77(7):470-476. [doi: 10.1016/j.ijmedinf.2007.08.009] [Medline: 17923433]

19. Xu CQ, Smith AC, Scuffham PA, Wootton R. A cost minimisation analysis of a telepaediatric otolaryngology service. BMC Health Serv Res 2008 Feb 04;8:30 [FREE Full text] [doi: 10.1186/1472-6963-8-30] [Medline: 18241356 ]

20. Armstrong AW, Dorer DJ, Lugn NE, Kvedar JC. Economic evaluation of interactive teledermatology compared with conventional care. Telemed J E Health 2007 Apr;13(2):91-99. [doi: 10.1089/tmj.2006.0035] [Medline: 17489695]

21. Smith AC, Scuffham P, Wootton R. The costs and potential savings of a novel telepaediatric service in Queensland. BMC Health Serv Res 2007 Mar 02;7:35 [FREE Full text] [doi: 10.1186/1472-6963-7-35] [Medline: 17331259]

22. Paré G, Sicotte C, St-Jules D, Gauthier R. Cost-minimization analysis of a telehomecare program for patients with chronic obstructive pulmonary disease. Telemed J E Health 2006 Apr;12(2):114-121. [doi: 10.1089/tmj.2006.12.114] [Medline: $\underline{16620165]}$

23. Labiris G, Tsitlakidis C, Niakas D. Retrospective economic evaluation of the Hellenic Air Force Teleconsultation Project. J Med Syst 2005 Oct;29(5):493-500. [doi: 10.1007/s10916-005-6106-4] [Medline: 16180485]

24. Norum J, Bruland $\varnothing$, Spanne O, Bergmo T, Green T, Olsen DR, et al. Telemedicine in radiotherapy: a study exploring remote treatment planning, supervision and economics. J Telemed Telecare 2005;11(5):245-250. [doi: 10.1258/1357633054471858] [Medline: 16035967]

25. Scuffham PA, Steed M. An economic evaluation of the Highlands and Islands Teledentistry Project. J Telemed Telecare 2016 Nov 29;8(3):165-177. [doi: 10.1177/1357633x0200800307]

26. Bjørvig S, Johansen MA, Fossen K. An economic analysis of screening for diabetic retinopathy. J Telemed Telecare 2002 Feb 01;8(1):32-35. [doi: 10.1258/1357633021937433]

27. Harno K, Arajärvi E, Paavola T, Carlson C, Viikinkoski P. Clinical effectiveness and cost analysis of patient referral by videoconferencing in orthopaedics. J Telemed Telecare 2001;7(4):219-225. [doi: 10.1258/1357633011936435] [Medline: 11506757]

28. Bergmo TS. A cost-minimization analysis of a realtime teledermatology service in northern Norway. J Telemed Telecare 2000 Oct 01;6(5):273-277. [doi: 10.1258/1357633001935905]

29. Harno K, Paavola T, Carlson C, Viikinkoski P. Patient referral by telemedicine: effectiveness and cost analysis of an Intranet system. J Telemed Telecare 2000;6(6):320-329. [doi: 10.1258/1357633001935996] [Medline: 11265100]

30. McCue MJ, Mazmanian PE, Hampton CL, Marks TK, Fisher EJ, Parpart F, et al. Cost-minimization analysis: a follow-up study of a telemedicine program. Telemed J 1998;4(4):323-327. [doi: 10.1089/tmj.1.1998.4.323] [Medline: 10220472]

31. McCue MJ, Mazmanian PE, Hampton C, Marks TK, Fisher E, Parpart F, et al. The case of Powhatan Correctional Center/Virginia Department of Corrections and Virginia Commonwealth University/Medical College of Virginia. Telemed J 1997;3(1):11-17. [doi: 10.1089/tmj.1.1997.3.11] [Medline: 10166440]

32. Loane MA, Oakley A, Rademaker M, Bradford N, Fleischl P, Kerr P, et al. A cost-minimization analysis of the societal costs of realtime teledermatology compared with conventional care: results from a randomized controlled trial in New Zealand. J Telemed Telecare 2001;7(4):233-238. [doi: 10.1258/1357633011936453] [Medline: 11506759]

33. Pak HS, Datta SK, Triplett CA, Lindquist JH, Grambow SC, Whited JD. Cost minimization analysis of a store-and-forward teledermatology consult system. Telemed J E Health 2009 Mar;15(2):160-165. [doi: 10.1089/tmj.2008.0083] [Medline: 19292625]

34. Snoswell CL, Taylor ML, Caffery LJ. The breakeven point for implementing telehealth. J Telemed Telecare 2019 Oct;25(9):530-536. [doi: 10.1177/1357633X19871403] [Medline: $\underline{31631758]}$

35. Pearl R. Kaiser Permanente Northern California: current experiences with internet, mobile, and video technologies. Health Aff (Millwood) 2014 Feb;33(2):251-257. [doi: 10.1377/hlthaff.2013.1005] [Medline: 24493768]

36. Chen YH, Lin YH, Hung CS, Huang CC, Yeih DF, Chuang PY, et al. Clinical outcome and cost-effectiveness of a synchronous telehealth service for seniors and nonseniors with cardiovascular diseases: quasi-experimental study. J Med Internet Res 2013 Apr 24;15(4):e87 [FREE Full text] [doi: 10.2196/jmir.2091] [Medline: 23615318]

37. Choi Yoo SJ, Nyman JA, Cheville AL, Kroenke K. Cost effectiveness of telecare management for pain and depression in patients with cancer: results from a randomized trial. Gen Hosp Psychiatry 2014;36(6):599-606 [FREE Full text] [doi: 10.1016/j.genhosppsych.2014.07.004] [Medline: 25130518]

38. Chung LMY, Law QPS, Fong SSM, Chung JWY, Yuen PP. A cost-effectiveness analysis of teledietetics in short-, intermediate-, and long-term weight reduction. J Telemed Telecare 2015 Jul;21(5):268-275. [doi:

10.1177/1357633X15572200] [Medline: 25761467] 
39. Comans T, Mihala G, Sakzewski L, Boyd RN, Scuffham P. The cost-effectiveness of a web-based multimodal therapy for unilateral cerebral palsy: the Mitii randomized controlled trial. Dev Med Child Neurol 2017 Jul;59(7):756-761. [doi: 10.1111/dmcn.13414] [Medline: 28247406]

40. Cubo E, Mariscal N, Solano B, Becerra V, Armesto D, Calvo S, et al. Prospective study on cost-effectiveness of home-based motor assessment in Parkinson's disease. J Telemed Telecare 2017 Feb;23(2):328-338. [doi: 10.1177/1357633X16638971] [Medline: 27000142]

41. Fusco F, Turchetti G. Telerehabilitation after total knee replacement in Italy: cost-effectiveness and cost-utility analysis of a mixed telerehabilitation-standard rehabilitation programme compared with usual care. BMJ Open 2016 May 17;6(5):e009964. [doi: 10.1136/bmjopen-2015-009964] [Medline: 27188803]

42. Ho YL, Yu JY, Lin YH, Chen YH, Huang CC, Hsu TP, et al. Assessment of the cost-effectiveness and clinical outcomes of a fourth-generation synchronous telehealth program for the management of chronic cardiovascular disease. J Med Internet Res 2014 Jun 10;16(6):e145 [FREE Full text] [doi: 10.2196/jmir.3346] [Medline: 24915187]

43. Richter KP, Shireman TI, Ellerbeck EF, Cupertino AP, Catley D, Cox LS, et al. Comparative and cost effectiveness of telemedicine versus telephone counseling for smoking cessation. J Med Internet Res 2015 May 08;17(5):e113 [FREE Full text] [doi: 10.2196/jmir.3975] [Medline: 25956257]

44. Isetta V, Lopez-Agustina C, Lopez-Bernal E, Amat M, Vila M, Valls C, et al. Cost-effectiveness of a new internet-based monitoring tool for neonatal post-discharge home care. J Med Internet Res 2013 Feb 18;15(2):e38 [FREE Full text] [doi: 10.2196/jmir.2361] [Medline: 23419609]

45. Boyne JJ, Di Van Asselt A, Gorgels AP, Steuten LM, De Weerd G, Kragten J, et al. Cost-effectiveness analysis of telemonitoring versus usual care in patients with heart failure: The TEHAF-study. J Telemed Telecare 2016 Jul 09;19(5):242-248. [doi: 10.1177/1357633x13495478]

46. Dear BF, Zou JB, Ali S, Lorian CN, Johnston L, Sheehan J, et al. Clinical and cost-effectiveness of therapist-guided internet-delivered cognitive behavior therapy for older adults with symptoms of anxiety: a randomized controlled trial. Behav Ther 2015 Mar;46(2):206-217. [doi: 10.1016/j.beth.2014.09.007] [Medline: 25645169]

47. Burns CL, Kularatna S, Ward EC, Hill AJ, Byrnes J, Kenny LM. Cost analysis of a speech pathology synchronous telepractice service for patients with head and neck cancer. Head Neck 2017 Dec;39(12):2470-2480. [doi: 10.1002/hed.24916] [Medline: 28963804]

48. Fortney JC, Pyne JM, Burgess JF. Population-Level Cost-Effectiveness of Implementing Evidence-Based Practices into Routine Care. Health Serv Res 2014 Oct 18;49(6):1832-1851. [doi: 10.1111/1475-6773.12247]

49. Frederix I, Hansen D, Coninx K, Vandervoort P, Vandijck D, Hens N, et al. Effect of comprehensive cardiac telerehabilitation on one-year cardiovascular rehospitalization rate, medical costs and quality of life: a cost-effectiveness analysis. Eur J Prev Cardiol 2016 May;23(7):674-682. [doi: 10.1177/2047487315602257] [Medline: 26289723]

50. Greving JP, Kaasjager HA, Vernooij JW, Hovens MM, Wierdsma J, Grandjean HM, et al. Cost-effectiveness of a nurse-led internet-based vascular risk factor management programme: economic evaluation alongside a randomised controlled clinical trial. BMJ Open 2015 May 20;5(5):e007128. [doi: 10.1136/bmjopen-2014-007128] [Medline: 25995238]

51. Henderson C, Knapp M, Fernández JL, Beecham J, Hirani SP, Beynon M, et al. Cost-effectiveness of telecare for people with social care needs: the Whole Systems Demonstrator cluster randomised trial. Age Ageing 2014 Nov;43(6):794-800 [FREE Full text] [doi: 10.1093/ageing/afu067] [Medline: 24950690]

52. Henderson C, Knapp M, Fernández JL, Beecham J, Hirani SP, Cartwright M, Whole System Demonstrator evaluation team. Cost effectiveness of telehealth for patients with long term conditions (Whole Systems Demonstrator telehealth questionnaire study): nested economic evaluation in a pragmatic, cluster randomised controlled trial. BMJ 2013 Mar 20;346:f1035. [doi: 10.1136/bmj.f1035] [Medline: 23520339]

53. Hofer F, Achelrod D, Stargardt T. Cost-utility analysis of telemonitoring interventions for patients with chronic obstructive pulmonary disease (COPD) in Germany. Appl Health Econ Health Policy 2016 Dec;14(6):691-701. [doi: 10.1007/s40258-016-0267-9] [Medline: 27475635]

54. Jódar-Sánchez F, Ortega F, Parra C, Gómez-Suárez C, Bonachela P, Leal S, et al. Cost-utility analysis of a telehealth programme for patients with severe chronic obstructive pulmonary disease treated with long-term oxygen therapy. $\mathrm{J}$ Telemed Telecare 2014 Sep;20(6):307-316 [FREE Full text] [doi: 10.1177/1357633X14544421] [Medline: 25052387]

55. Kaambwa B, Bryan S, Jowett S, Mant J, Bray EP, Hobbs FDR, et al. Telemonitoring and self-management in the control of hypertension (TASMINH2): a cost-effectiveness analysis. Eur J Prev Cardiol 2014 Dec;21(12):1517-1530. [doi: 10.1177/2047487313501886] [Medline: 23990660]

56. Kidholm K, Rasmussen MK, Andreasen JJ, Hansen J, Nielsen G, Spindler H, et al. Cost-utility analysis of a cardiac telerehabilitation program: the teledialog project. Telemed J E Health 2016 Jul;22(7):553-563 [FREE Full text] [doi: 10.1089/tmj.2015.0194] [Medline: 26713491]

57. Mistry H, Gardiner HM. The cost-effectiveness of prenatal detection for congenital heart disease using telemedicine screening. J Telemed Telecare 2013 Jun;19(4):190-196. [doi: 10.1258/jtt.2012.120418] [Medline: 23576807]

58. Naveršnik K, Mrhar A. Cost-effectiveness of a novel e-health depression service. Telemed J E Health 2013 Feb;19(2):110-116. [doi: 10.1089/tmj.2012.0081] [Medline: 23374036] 
59. Nelson RE, Okon N, Lesko AC, Majersik JJ, Bhatt A, Baraban E. The cost-effectiveness of telestroke in the Pacific Northwest region of the USA. J Telemed Telecare 2016 Oct;22(7):413-421. [doi: 10.1177/1357633X15613920] [Medline: 26541170]

60. Nguyen HV, Tan GSW, Tapp RJ, Mital S, Ting DSW, Wong HT, et al. Cost-effectiveness of a national telemedicine diabetic retinopathy screening program in Singapore. Ophthalmology 2016 Dec;123(12):2571-2580. [doi: 10.1016/j.ophtha.2016.08.021] [Medline: 27726962]

61. Nguyen KH, Smith AC, Armfield NR, Bensink M, Scuffham PA. Cost-effectiveness analysis of a mobile ear screening and surveillance service versus an outreach screening, surveillance and surgical service for indigenous children in Australia. PLoS One 2015;10(9):e0138369 [FREE Full text] [doi: 10.1371/journal.pone.0138369] [Medline: 26406592]

62. Rachapelle S, Legood R, Alavi Y, Lindfield R, Sharma T, Kuper H, et al. The cost-utility of telemedicine to screen for diabetic retinopathy in India. Ophthalmology 2013 Mar;120(3):566-573. [doi: 10.1016/j.ophtha.2012.09.002] [Medline: $\underline{23211635}$

63. Stoddart A, van der Pol M, Pinnock H, Hanley J, McCloughan L, Todd A, et al. Telemonitoring for chronic obstructive pulmonary disease: a cost and cost-utility analysis of a randomised controlled trial. J Telemed Telecare 2015 Mar;21(2):108-118. [doi: 10.1177/1357633X14566574] [Medline: 25586810]

64. Titov N, Dear BF, Ali S, Zou JB, Lorian CN, Johnston L, et al. Clinical and cost-effectiveness of therapist-guided internet-delivered cognitive behavior therapy for older adults with symptoms of depression: a randomized controlled trial. Behav Ther 2015 Mar;46(2):193-205. [doi: 10.1016/j.beth.2014.09.008] [Medline: 25645168]

65. Zanaboni P, Landolina M, Marzegalli M, Lunati M, Perego GB, Guenzati G, et al. Cost-utility analysis of the EVOLVO study on remote monitoring for heart failure patients with implantable defibrillators: randomized controlled trial. J Med Internet Res 2013 May 30;15(5):e106 [FREE Full text] [doi: 10.2196/jmir.2587] [Medline: 23722666]

66. Thomas S, Hodge W, Malvankar-Mehta M. The cost-effectiveness analysis of teleglaucoma screening device. PLoS One 2015;10(9):e0137913 [FREE Full text] [doi: 10.1371/journal.pone.0137913] [Medline: 26382956]

67. Dixon P, Hollinghurst S, Edwards L, Thomas C, Gaunt D, Foster A, et al. Cost-effectiveness of telehealth for patients with raised cardiovascular disease risk: evidence from the Healthlines randomised controlled trial. BMJ Open 2016 Aug 26;6(8):e012352. [doi: 10.1136/bmjopen-2016-012352] [Medline: 27566642]

68. Isetta V, Negrín MA, Monasterio C, Masa JF, Feu N, Álvarez A, SPANISH SLEEP NETWORK. A Bayesian cost-effectiveness analysis of a telemedicine-based strategy for the management of sleep apnoea: a multicentre randomised controlled trial. Thorax 2015 Nov;70(11):1054-1061. [doi: 10.1136/thoraxjnl-2015-207032] [Medline: 26310452]

69. Tengs TO, Wallace A. One thousand health-related quality-of-life estimates. Med Care 2000 Jun;38(6):583-637. [doi: 10.1097/00005650-200006000-00004] [Medline: 10843310]

70. Dimmick SL, Mustaleski C, Burgiss SG, Welsh T. Home Healthc Nurse 2000 Feb;18(2): 124-135. [doi: 10.1097/00004045-200002000-00013] [Medline: 11040644]

71. Schaafsma J, Pantazi SV, Moehr JR, Anglin CR, Grimm NA. An economic evaluation of a telehealth network in British Columbia. J Telemed Telecare 2007 Jul 01;13(5):251-256. [doi: 10.1258/135763307781458877]

72. Benger JR, Noble SM, Coast J, Kendall JM. The safety and effectiveness of minor injuries telemedicine. Emerg Med J 2004 Jul;21(4):438-445. [Medline: 15208226]

73. Oakley AM, Kerr P, Duffill M, Rademaker M, Fleischl P, Bradford N, et al. Patient cost-benefits of realtime teledermatology--a comparison of data from Northern Ireland and New Zealand. J Telemed Telecare 2000;6(2):97-101. [doi: 10.1258/1357633001935112] [Medline: 10824377 ]

74. Viers BR, Lightner DJ, Rivera ME, Tollefson MK, Boorjian SA, Karnes RJ, et al. Efficiency, satisfaction, and costs for remote video visits following radical prostatectomy: a randomized controlled trial. Eur Urol 2015 Oct;68(4):729-735. [doi: 10.1016/j.eururo.2015.04.002] [Medline: 25900782]

75. Agha Z, Roter DL, Schapira RM. An evaluation of patient-physician communication style during telemedicine consultations. J Med Internet Res 2009 Sep 30;11(3):e36 [FREE Full text] [doi: 10.2196/jmir.1193] [Medline: 19793720]

76. Buvik A, Bugge E, Knutsen G, Småbrekke A, Wilsgaard T. Quality of care for remote orthopaedic consultations using telemedicine: a randomised controlled trial. BMC Health Serv Res 2016 Sep 8;16(1):483. [doi: 10.1186/s12913-016-1717-7]

77. Nordal EJ, Moseng D, Kvammen B, Løchen M. A comparative study of teleconsultations versus face-to-face consultations. J Telemed Telecare 2001 Oct 01;7(5):257-265. [doi: 10.1258/1357633011936507]

78. Greenhalgh T, Shaw S, Wherton J, Vijayaraghavan S, Morris J, Bhattacharya S, et al. Real-world implementation of video outpatient consultations at macro, meso, and micro levels: mixed-method study. J Med Internet Res 2018 Apr 17;20(4):e150 [FREE Full text] [doi: 10.2196/jmir.9897] [Medline: 29625956]

79. Wade V. How to Make Telehealth Work: Defining Telehealth Processes and Procedures.: Adelaide Unicare; 2013. URL: https://www.petermac.org/sites/default/files/media-uploads/How to Make telehealth Work \%28Victoria\%20Wade\%29. pdf [accessed 2019-11-26]

80. Blount Y, Gloet M. Adoption of ICT Enabled Telehealth Services in the Australian Context: Implications of Technology Use for Telehealth Workers. 2015 Presented at: 48th Hawaii International Conference on System Sciences; Jan. 52015 to Jan. 8 2015; Hawaii, USA. [doi: 10.1109/hicss.2015.430] 
81. Eminović N, Dijkgraaf MG, Berghout RM, Prins AH, Bindels PJ, de Keizer NF. A cost minimisation analysis in teledermatology: model-based approach. BMC Health Serv Res 2010 Aug 25;10:251 [FREE Full text] [doi: 10.1186/1472-6963-10-251] [Medline: 20738871]

82. Liddy C, Moroz I, Afkham A, Keely E. Evaluating the implementation of The Champlain BASETM eConsult Service in a new region of Ontario, Canada: a cross-sectional study. Healthc Policy 2017 Nov 30;13(2):79-95. [doi: 10.12927/hcpol.2017.25320]

83. Steventon A, Ariti C, Fisher E, Bardsley M. Effect of telehealth on hospital utilisation and mortality in routine clinical practice: a matched control cohort study in an early adopter site. BMJ Open 2016 Feb 03;6(2):e009221. [doi: 10.1136/bmjopen-2015-009221] [Medline: 26842270]

84. Snoswell CL, Caffery LJ, Whitty JA, Soyer HP, Gordon LG. Cost-effectiveness of skin cancer referral and consultation using teledermoscopy in Australia. JAMA Dermatol 2018 Jun 01;154(6):694-700 [FREE Full text] [doi:

10.1001/jamadermatol.2018.0855] [Medline: 29801161]

85. Loane M, Bloomer S, Corbett R, Eedy D, Hicks N, Lotery H, et al. A comparison of real-time and store-and-forward teledermatology: a cost-benefit study. Br J Dermatol 2000 Dec;143(6):1241-1247. [doi: 10.1046/j.1365-2133.2000.03895.x] [Medline: 11122028 ]

86. Liederman EM, Lee JC, Baquero VH, Seites PG. The impact of patient-physician Web messaging on provider productivity. J Healthc Inf Manag 2005;19(2):81-86. [Medline: 15869217]

87. Cheung CMM, Muttardi K, Chinthapalli S, Ismail F. Pilot teledermatology service for assessing solitary skin lesions in a tertiary London dermatology center. J Healthc Qual 2019;41(1):e1-e6. [doi: 10.1097/JHQ.0000000000000142] [Medline: 29634594]

88. Hager B, Hasselberg M, Arzubi E, Betlinski J, Duncan M, Richman J, et al. Leveraging behavioral health expertise: practices and potential of the Project ECHO approach to virtually integrating care in underserved areas. Psychiatr Serv 2018 Apr 01;69(4):366-369. [doi: 10.1176/appi.ps.201700211] [Medline: 29446334]

89. World Health Organisation. Building the economic case for primary health care: a scoping review. 2018 May 08. URL: https://www.who.int/publications/i/item/WHO-HIS-SDS-2018.48 [accessed 2019-11-26]

90. Comín-Colet J, Enjuanes C, Verdú-Rotellar JM, Linas A, Ruiz-Rodriguez P, González-Robledo G, et al. Impact on clinical events and healthcare costs of adding telemedicine to multidisciplinary disease management programmes for heart failure: Results of a randomized controlled trial. J Telemed Telecare 2016 Jul;22(5):282-295. [doi: 10.1177/1357633X15600583] [Medline: 26350543]

91. Boulé S, Ninni S, Finat L, Botcherby EJ, Kouakam C, Klug D, et al. Potential role of antitachycardia pacing alerts for the reduction of emergency presentations following shocks in patients with implantable cardioverter-defibrillators: implications for the implementation of remote monitoring. Europace 2016 Dec;18(12):1809-1817. [doi: 10.1093/europace/euv392] [Medline: 26711741]

92. Celler B, Varnfield M, Sparks R, Li J, Nepal S, Jang-Jaccard J. Home Monitoring of Chronic Disease for Aged Care.: Australian e-Health Research Centre, CSIRO; 2016 May. URL: https://www.csiro.au/ /media/BF/Files/ Telehealth-Trial-Final-Report-May-2016 3-Final.pdf [accessed 2019-11-26]

93. Steventon A, Bardsley M, Billings J, Dixon J, Doll H, Hirani S, Whole System Demonstrator Evaluation Team. Effect of telehealth on use of secondary care and mortality: findings from the Whole System Demonstrator cluster randomised trial. BMJ 2012 Jun 21;344:e3874 [FREE Full text] [doi: 10.1136/bmj.e3874] [Medline: 22723612]

94. Woods LW, Snow SW. The impact of telehealth monitoring on acute care hospitalization rates and emergency department visit rates for patients using home health skilled nursing care. Home Healthc Nurse 2013 Jan;31(1):39-45. [doi: 10.1097/NHH.0b013e3182778dd3] [Medline: 23238623]

95. Takahashi PY, Pecina JL, Upatising B, Chaudhry R, Shah ND, Van Houten H, et al. A randomized controlled trial of telemonitoring in older adults with multiple health issues to prevent hospitalizations and emergency department visits. Arch Intern Med 2012 May 28;172(10):773-779 [FREE Full text] [doi: 10.1001/archinternmed.2012.256] [Medline: 22507696]

96. Jiménez-Marrero S, Yun S, Cainzos-Achirica M, Enjuanes C, Garay A, Farre N, et al. Impact of telemedicine on the clinical outcomes and healthcare costs of patients with chronic heart failure and mid-range or preserved ejection fraction managed in a multidisciplinary chronic heart failure programme: A sub-analysis of the iCOR randomized trial. J Telemed Telecare 2020;26(1-2):64-72. [doi: 10.1177/1357633X18796439] [Medline: 30193564]

97. Lew SQ, Sikka N, Thompson C, Magnus M. Impact of remote biometric monitoring on cost and hospitalization outcomes in peritoneal dialysis. J Telemed Telecare 2019 Dec;25(10):581-586. [doi: 10.1177/1357633X18784417] [Medline: 30001668]

98. Ehlert A, Oberschachtsiek D. Can telehealth reduce health care expenditure? A lesson from German health insurance data. Int J Health Plann Manage 2019 Oct;34(4):1121-1132. [doi: 10.1002/hpm.2764] [Medline: 30924194]

99. Langabeer JR, Gonzalez M, Alqusairi D, Champagne-Langabeer T, Jackson A, Mikhail J, et al. Telehealth-enabled emergency medical services program reduces ambulance transport to urban emergency departments. West J Emerg Med 2016 Nov;17(6):713-720 [FREE Full text] [doi: 10.5811/westjem.2016.8.30660] [Medline: 27833678] 
100. Gillespie SM, Shah MN, Wasserman EB, Wood NE, Wang HY, Noyes K, et al. Reducing emergency department utilization through engagement in telemedicine by senior living communities. Telemed J E Health 2016 Jun;22(6):489-496. [doi: 10.1089/tmj.2015.0152] [Medline: 26741194]

101. Caffery LJ, Farjian M, Smith AC. Telehealth interventions for reducing waiting lists and waiting times for specialist outpatient services: a scoping review. J Telemed Telecare 2016 Dec;22(8):504-512. [doi: 10.1177/1357633X16670495] [Medline: 27686648]

102. Ashwood JS, Mehrotra A, Cowling D, Uscher-Pines L. Direct-to-consumer telehealth may increase access to care but does not decrease spending. Health Aff (Millwood) 2017 Mar 01;36(3):485-491. [doi: 10.1377/hlthaff.2016.1130] [Medline: 28264950]

103. Qoctor. Dr Sicknote rebrands as qoctor 2018. 2017. URL: https://www.qoctor.com.au/drsicknote_rebrands_as_qoctor/ [accessed 2019-11-26]

104. iDoc. iDoc24 Research. 2016. URL: https://www.idoc24.com/about/background-research/ [accessed 2019-11-26]

105. Zhou C, Crawford A, Serhal E, Kurdyak P, Sockalingam S. The impact of Project ECHO on participant and patient outcomes: a systematic review. Acad Med 2016 Oct;91(10):1439-1461. [doi: 10.1097/ACM.0000000000001328] [Medline: 27489018]

106. Fisher E, Hasselberg M, Conwell Y, Weiss L, Padrón NA, Tiernan E, et al. Telementoring primary care clinicians to improve geriatric mental health care. Popul Health Manag 2017 Oct;20(5):342-347. [doi: 10.1089/pop.2016.0087] [Medline: 28106511]

107. Rattay T, Dumont IP, Heinzow HS, Hutton DW. Cost-effectiveness of access expansion to treatment of hepatitis C virus infection through primary care providers. Gastroenterology 2017 Dec;153(6):1531-1543.e2. [doi: 10.1053/j.gastro.2017.10.016] [Medline: 29074450]

108. Wade V, Soar J, Gray L. Uptake of telehealth services funded by Medicare in Australia. Aust Health Rev 2014 Nov;38(5):528-532. [doi: 10.1071/AH14090] [Medline: 25219655]

109. Ford JA, Pereira A. Does teledermatology reduces secondary care referrals and is it acceptable to patients and doctors?: a service evaluation. J Eval Clin Pract 2015 Aug;21(4):710-716. [doi: 10.1111/jep.12373] [Medline: 25903046]

110. Jones MD, Etherage JR, Harmon SC, Okiishi JC. Acceptability and cost-effectiveness of military telehealth mental health screening. Psychol Serv 2012 May;9(2):132-143. [doi: 10.1037/a0026709] [Medline: 22662728]

111. Caffery LJ, Taylor M, Lucas K, Smith AC. Substitution rates of video consultations for traditional consultations at a tertiary public hospital. J Telemed Telecare 2016 Dec;22(8):453-458. [doi: 10.1177/1357633X16672767] [Medline: 27799447]

112. Medical Services Advisory Committee. 1360.1 - Specialist dermatology services delivered by asynchronous store and forward technology (resubmission). Canberra: Australian Government, Department of Health; 2017 Aug 03. URL: http:/ /www.msac.gov.au/internet/msac/publishing.nsf/Content/1360.1-public [accessed 2019-11-26]

\author{
Abbreviations \\ CEA: cost-effectiveness analysis \\ CHEERS: Consolidated Health Economic Evaluation Reporting Standards \\ CMA: cost-minimization analysis \\ CUA: cost-utility analysis \\ ED: emergency department \\ GDP: gross domestic product \\ HRQoL: health-related quality of life \\ PRISMA-ScR: Preferred Reporting Items for Systematic reviews and Meta-Analyses extension for Scoping \\ Reviews \\ Project ECHO: Project Extension for Community Healthcare Outcomes \\ QALYs: quality-adjusted life years \\ RCTs: randomized controlled trials
}

Edited by G Eysenbach; submitted 04.12.19; peer-reviewed by B Smith, K Okamoto; comments to author 07.07.20; revised version
received 02.08.20; accepted 17.08.20; published 19.10.20
Please cite as:
Snoswell CL, Taylor ML, Comans TA, Smith AC, Gray LC, Caffery LJ
Determining if Telehealth Can Reduce Health System Costs: Scoping Review
J Med Internet Res 2020;22(10):e17298
URL: $\underline{\text { http://www.jmir.org/2020/10/e17298/ }}$
doi: $10.2196 / 17298$
PMID: $\underline{3074157}$


(C) Centaine L Snoswell, Monica L Taylor, Tracy A Comans, Anthony C Smith, Leonard C Gray, Liam J Caffery. Originally published in the Journal of Medical Internet Research (http://www.jmir.org), 19.10.2020. This is an open-access article distributed under the terms of the Creative Commons Attribution License (https://creativecommons.org/licenses/by/4.0/), which permits unrestricted use, distribution, and reproduction in any medium, provided the original work, first published in the Journal of Medical Internet Research, is properly cited. The complete bibliographic information, a link to the original publication on http://www.jmir.org/, as well as this copyright and license information must be included. 